\title{
Fault geometry and evidence of depocentre migration within a transtensional intra-basinal high - a case study from the Łączna Anticline (Intrasudetic Synclinorium, SW Poland)
}

\author{
Aleksander KOWALSKI ${ }^{1, *}$ \\ 1 University of Wrocław, Institute of Geological Sciences, Department of Structural Geology and Geological Mapping, \\ pl. M. Borna 9, 50-204 Wrocław, Poland
}

Kowalski, A., 2017. Fault geometry and evidence of depocentre migration within a transtensional intra-basinal high - a case study from the Łączna Anticline (Intrasudetic Synclinorium, SW Poland). Geological Quarterly, 61 (4): 779-794, doi: 10.7306/gq.1372

\begin{abstract}
The paper presents the results of geological mapping and a detailed structural analysis carried out in the $Ł a ̨ c z n a$ Anticline. This elevated region coincides with the Zawory (Cz. Závora) mountain range in the Central Sudetes (SW Poland). The Łączna Anticline separates two minor geological units (depressions) within the northwestern part of the Intrasudetic Synclinorium - the Krzeszów and the Police brachysynclines. In numerous exposures of Triassic and Upper Cretaceous sedimentary rocks, several brittle and a few soft-sediment deformation structures have been recognized. Their orientation and spatial distribution suggest that the Łaczna Anticline is a horst-like, intra-basinal high, formed due to permanent extension, dextral strike-slip movements within fault zones, and negative flower structures. The studies did not confirm the occurrence of continuous deformations such as anticlinal bends and flexures. The results show that the preservation of some lithological varieties of sedimentary rocks within modern morphological and structural elevations reflects the migration of centres of maximum subsidence within a pull-apart basin system. A new structural and geodynamic interpretation for the Łączna Anticline area is proposed.
\end{abstract}

Key words: pull-apart basins, intra-basinal highs, brittle tectonics, strike-slip tectonics, Sudetes, Intrasudetic Synclinorium.

\section{INTRODUCTION}

Intra-basinal highs, also known as central basin horsts (Sims et al., 1999; Dooley and Schreurs, 2012), are very common structural elements observed within extensional basins, particularly in a transtensional setting (Anders and Schlische, 1994; Hölzel et al., 2008; Wu et al., 2009). Their evolution and geometry are linked with cross-basin fault zones (CBFZs Dooley et al., 2004) that led to the formation of uplifted, horst-like structures in the central part of the basin. Similarly to intra-basinal "pop-up structures" (McClay and Bonora, 2001) formed in a transpressional regime, transtensional intra-basinal highs are topographic elevations with older rocks exposed in the core (Sylvester, 1988; Sugan et al., 2014). They have strongly influenced the sedimentation and migration of depocentres within pull-apart basins (Wu et al., 2009). Several morphological, intra-basinal elevations (Uličný, 2001; Wojewoda, 2007, 2009) have been recognized and described within the Intrasudetic Synclinorium (IS) - a distinct intramontane depression situated in the northeastern termination of

\section{*E-mail: aleksander.kowalski@uwr.edu.pl}

Received: January 31, 2017; accepted: June 2, 2017; first published online: August 1, 2017 the Bohemian Massif (Fig. 1). The IS is the largest geological unit ( $70 \mathrm{~km}$ long and $35 \mathrm{~km}$ wide) of the Sudetes and is built of a weakly deformed sedimentary succession of the Intrasudetic Basin. The basin infill comprises Mississippian to Lower Permian volcaniclastic rocks, which are unconformably overlain by Triassic continental and Cretaceous marine sediments. Development of the Intrasudetic Basin as a narrow intramontane trough (Wojewoda and Mastalerz, 1989) was initiated probably in the Middle or Early to Late Visean times (Nemec et al., 1982; Turnau et al., 2002), especially in an extensional strike-slip setting (Porębski, 1980; Wojewoda, 1997; Aleksandrowski, 1998). The Intrasudetic Basin was filled with clastic, mainly continental deposits during Mississippian to Early Permian times. The basin infilling process was interrupted by sub-volcanic intrusions and tectonic deformations before the end of the Pennsylvanian (the first stage of basin inversion; according to Żelaźniewicz et al., 2011). The youngest, Late Cretaceous (Ziegler, 1987; Mazur et al., 2006) and Neogene (Wojewoda, 2004) inversions of the basin resulted in the formation of numerous structural depressions ("sub-basins"; Uličný, 1999) bounded by NW-SE-trending normal and strike-slip faults (Wojewoda, 1997; Uličný, 2001; Grygar and Jelinek, 2003; Wojewoda, 2007). The sub-basins within the IS are interpreted as individual pull-apart basins (Uličný, 2001; Wojewoda, 2007) separated by transversely oriented elevations (Wojewoda and Mastalerz, 1989). This paper presents the results of geological mapping and structural analysis of the Łączna Anticline area (LA; Ger. 


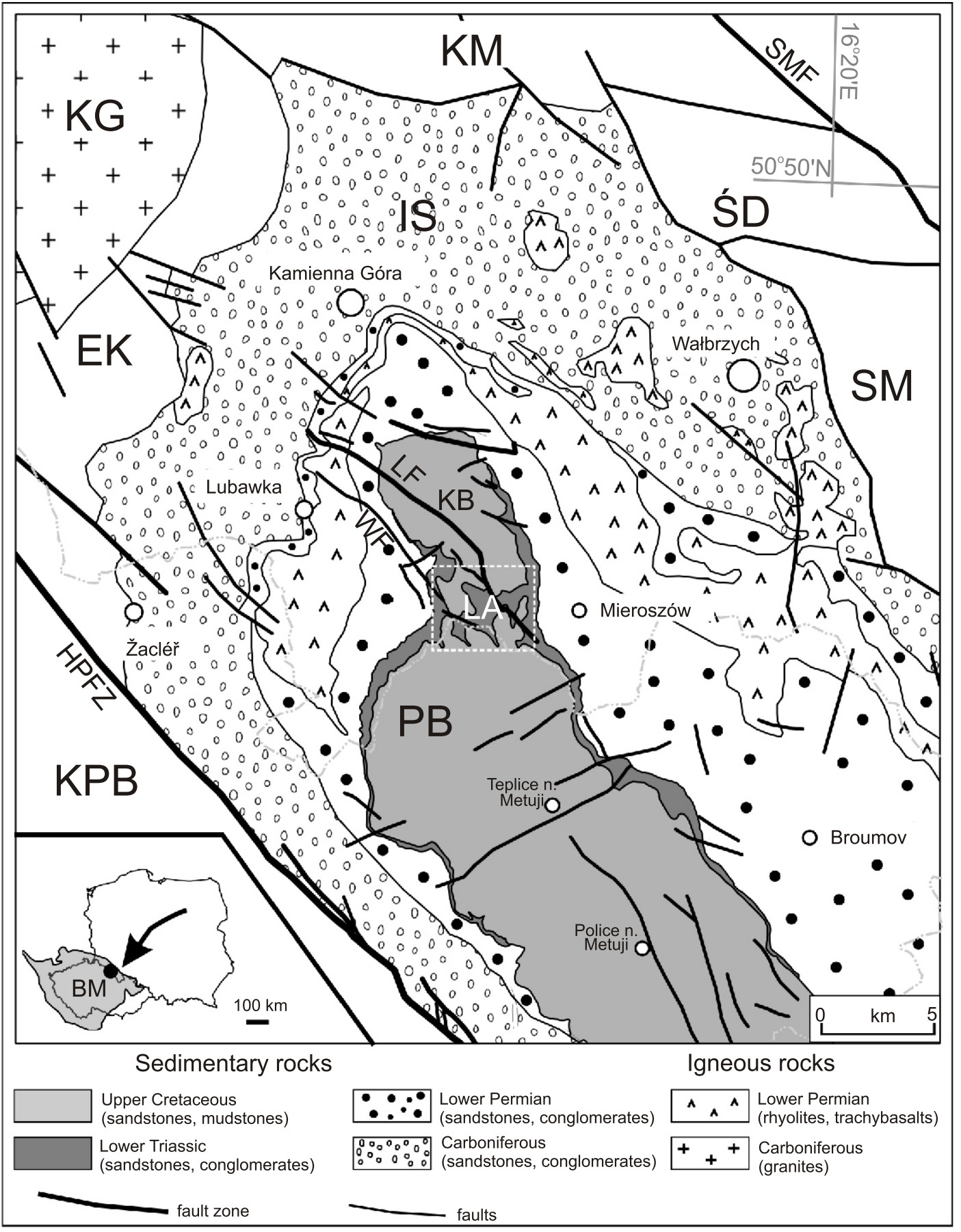

Fig. 1. Simplified geological sketch-map of the northern part of the Intrasudetic Synclinorium with location of the Kączna Anticline (LA)

BM - Bohemian Massif; EK - East Karkonosze Metamorphic Unit; HPFZ - Hronov-Pořiči Fault Zone; IS Intrasudetic Synclinorium; KB - Krzeszów Brachysyncline; KG - Karkonosze Granite Pluton; KM - Kaczawa Metamorphic Complex; KPB - Karkonosze Piedmont Basin; LF - Lipienica-Łączna Fault; PB - Police Brachysyncline; SM - Góry Sowie Gneiss Massif; SMF - Sudetic Marginal Fault; ŚD - Świebodzice Depression; WF - Wójtowa Fault; simplified after Grocholski (1971), Don et al. (1981) and Cymerman (2004)

Raspenauer Sattel; Petrascheck, 1933; Jerzykiewicz, 1969). The presented investigations suggest that the Łączna Anticline constitutes an intra-basinal high that separates two minor, NW-SE-trending depressions within the IS: the Krzeszów and Police brachysynclines (KB and PB sub-basins, respectively; Jerzykiewicz, 1969; Tásler et al., 1979).

\section{GEOLOGICAL SETTING}

The study area is located at the Czech-Polish border, within the northwestern part of the Intrasudetic Synclinorium, between the towns of Lubawka and Mieroszów (Fig. 1). According to regional physiographical divisions (Kondracki, 2002), the region is 
assigned to the Zawory Range ( $\mathrm{Cz}$. Závora) that constitutes the northernmost part of the Stołowe Mountains in the Central Sudetes. Sedimentary rocks exposed in the area represent Permian (Rotliegend), Triassic (Buntsandstein) and Cretaceous (Upper Cenomanian) deposits (Fig. 2). In the peripheral parts of the basin occur the oldest, Lower Permian sediments, included in the Radków Formation in the Polish part of the IS (Nemec et al., 1982) or in the Trutnov Formation in the Czech part of the IS (Tásler, 1964). Lower Permian sediments consist mostly of coarse-grained conglomerates ("fanglomerates"; Dziedzic, 1961) and conglomeratic sandstones interpreted as alluvial fan and braided river deposits (Aleksandrowski et al., 1986; Wojewoda, 2008). Sediments of the Radków (Trutnov) Formation pass upward into sandy conglomerates with calcareous intercalations and dolomites of the Chełmsko Śląskie Beds (Dziedzic, 1961; Śliwiński, 1984) or of the Bohuslavice Formation in the Czech part of the IS (Tásler et al., 1964). These deposits are classified as late Saxonian (Śliwiński, 1984) or Thuringian (Holub, 1972) in age, respectively. They are interpreted as fluvial and lacustrine deposits (Tásler, 1979) with calcrete (caliche) and travertine horizons (Śliwiński, 1981, 1984). Lower Triassic arkosic sandstones of the Bohdašín Formation (Tásler, 1964; Prouza et al., 1985) nearly concordantly overlie Permian deposits and are considered as typical braided river and alluvial fan deposits (Mroczkowski, 1977; Prouza et al., 1985). The topmost part of the Bohdašín Formation consists of strongly kaolinized, weakly lithified sandstones of undefined age (Middle Triassic?), which occur only locally in the IS (Wojewoda et al., 2016). They were first distinguished in the Czech part of the IS as the Devět krrižů or the Barchoviny Member sandstones (Holub, 1966; 1972). Kaolinitic sandstones were interpreted as shallow marine (Holub, 1966; Wojewoda et al., 2016), lacustrine (Prouza et al., 1985) or even aeolian sediments (Mikulaš et al., 1991; Uličný, 2004). In the study area, the sandstones of the Bohdašín Formation crop out mainly in the vicinity of Łączna (Czarna Struga Valley) and are discordantly covered by Cretaceous strata. The boundary between the Triassic and Cretaceous sediments corresponds to the bottom of the "basal conglomerates" (Skoček and Valečka, 1983) that mark a nearly horizontal transgressive surface. Cretaceous marine sediments occur in the central parts of the brachysynclines and build the hills surrounding them. Between the Krzeszów and Police brachysynclines, the sandy facies of these strata (glauconitic and calcareous sandstones) are assigned to the Upper Cenomanian (Peruc-Koryčany Formation; Dvořák, 1968; Jerzykiewicz, 1971). The sandstones pass upward into glauconitic and siliceous mudstones (gaizes and spongiolites) assigned to the Upper Cenomanian (Jerzykiewicz, 1971) and Lower Turonian (Bílá Hora Formation; Dvořák, 1968). Mudstones build the highest elevations of the region. Glauconitic mudstones ("glauconite horizon"; Berg, 1909) thin out to the south within the siliceous mudstones (Berg, 1909; Jerzykiewicz, 1971; Ziółkowska, 1990). The fine-grained deposits pass upward into Middle and Upper Turonian calcareous mudstones and sandstones outcropping in the central parts of the KB and PB. Cretaceous rocks, which crop out within the IS, constitute the western part of a larger regional geological unit the Bohemian Cretaceous Basin (Skoček and Valečka, 1983), located in the central part of the Bohemian Massif. It is worth mentioning that the Triassic and Cretaceous strata of the Krzeszów Basin constitute also the northernmost part of the existing Mesozoic sedimentary cover of the IS.

The tectonic setting of the Łączna area is poorly recognized. According to Jerzykiewicz (1969) and Don et al. (1981), the northern part of the Zawory Range (a mountain belt comprising the Róg, Drogosz and Chochoł hills; Puc and Traczyk, 2006),

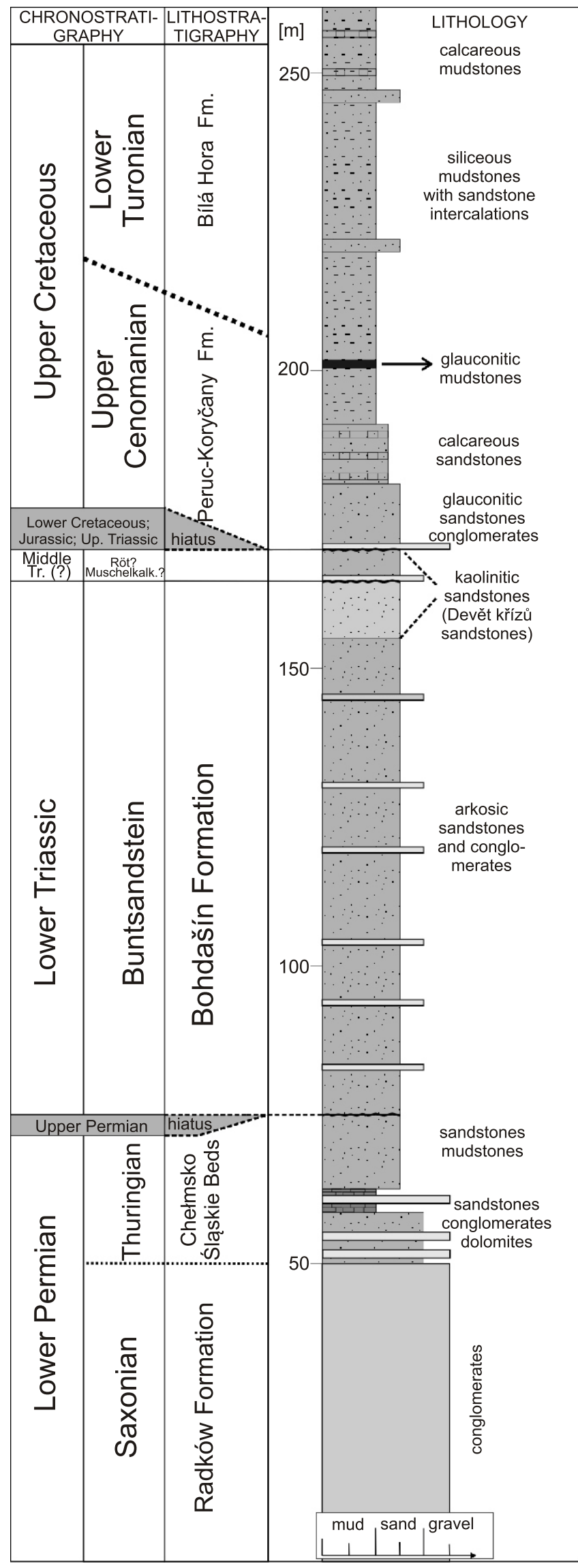

Fig. 2. Stratigraphy and lithology of the Łączna Anticline area 
along with the Czarna Struga Valley, indicate the axis of the Łączna Brachyanticline. Jerzykiewicz (1971) argued that the well-exposed Buntsandstein sediments mark here the core of an open fold (dome). The hypothetical axis of the Łączna Brachyanticline is perpendicular to the axis of the Krzeszów and Police brachysynclines (Petrascheck, 1933; Jerzykiewicz, 1971). According to these authors, Cretaceous and Triassic strata in the Łączna region lie horizontally or dip gently towards the north within the Southern Marginal Flexure of the Krzeszów Brachysyncline (Jerzykiewicz, 1971). Jerzykiewicz (1971) speculated also that the Southern Marginal Flexure simultaneously constitutes the northern limb of the Łączna Brachyanticline. Accordingly, the southern slopes of the Mielna and Róg hills coincide with the northern flexure of the PB (SF Fig. 3; southern limb of the LA). The presence of flexure-related bends was postulated, among others, on the northern slope of the Drogosz Hill. Tułaczyk (1992) claimed that the structure of the Łączna Brachyanticline is complicated and determines the shape of scarps and cuesta ridges. It is important to note that the Krzeszów Brachysyncline was always considered as a single brachyfold (Jerzykiewicz, 1971; Don et al., 1981), although the Police Brachysyncline (Police subbasin sensu Uličný, 2001) was subdivided by some authors into three minor tectonic units: the Adršpach, Police (Wojewoda et al., 2016) and Batorów brachysynclines (Radwański, 1966).

All lithological varieties of sedimentary rocks that crop out in the KB and PB are deformed by vertical or sub-vertical sets of joints. Orthogonal and nearly orthogonal joint systems can be observed, among others, in the exposures of Cretaceous strata, especially within jointed glauconitic sandstones. The term "Jointed Sandstones" (Ger. Quadersandstein; hereinafter: Quader) has already been applied to the Cretaceous sandstones cropping out in the northern part of Bohemia, Saxony and Silesia (Raumer, 1819; Geinitz, 1848; Flegel, 1904). These sandstones are subdivided into three main horizons: Lower, Middle and Upper Quader, respectively (e.g., Geinitz, 1848; Flegel, 1904; Wojewoda, 1997). Joints within the glauconitic sandstones in the Łączna region are grouped in NNW-SSE and WSW-ENE-trending conjugate sets. Their orientation highly coincides with the regional direction of orthogonal joint systems in other parts of the IS (Jerzykiewicz, 1968). Fractures cutting the glauconitic and siliceous mudstones are denser and less regular than the joints within the sandstones.

Both normal and strike-slip NW-SE-oriented faults are also significant structural elements of the study area. Several faults were identified using cartographic methods between the KB and $\mathrm{PB}$. The most important fault zone recognized in the vicinity of Łączna is the Lipienica-Łączna Fault (LF; Fig. 1; Don et al., 1979; 1981), which was marked on geological maps as a single NW-SE-trending fault (Berg and Dathe, 1905/1906; Jerzykiewicz, 1971; Grocholski, 1971, Don et al., 1979). The second important fault zone, called the Wójtowa Fault (WF; Fig.1; Don et al., 1981), cuts Permian sediments on the western slope of Róg Hill. Furthermore, there are a few unnamed faults cutting the sedimentary strata between the KB and PB (Jerzykiewicz, 1971; Don et al., 1979), especially on the western slopes of Róg Hill, and between Rogal and Dziób hills to the south of the village of Łączna.

\section{METHODS}

Geological and structural mapping of the Łączna region was conducted in numerous localities including abandoned and periodically active quarries, road crosscuts and natural exposures. Representative samples of the main lithological types were collected. Textural and structural features of selected Triassic and Cretaceous sandstones were analysed during fieldwork and supplemented with petrographic microscopic observations. Structural mapping involved measurements and description of joints, fault planes, and preserved fault scarps. Numerous mesostructural kinematic indicators (Petit, 1987), such as striated ridges, grooves, slickensides, low-angle shears, hackles and en echelon cracks, were described and measured (Table 1). The measurements were plotted using a lower hemisphere stereographic projection.

During fieldwork, much attention was paid to accurate localization and type of lithological boundaries (tectonic and sedimentary contacts). In many cases, basic geomorphological mapping and observations were carried out. Structural features were identified and precisely localized in the field with application of the Nomad Trimble GPS and Pentagram PathFinder Logger P3106. The effect of the investigations - a geological map at the scale of $1: 10,000$, was superimposed on a shaded LiDAR Digital Terrain Model (DTM) of $\sim 1 \mathrm{~m}$ resolution (Fig. 3). Contours generated from the DTM had a $0.5 \mathrm{~m}$ interval and were applied to construct regional stratigraphic and structural surfaces with the use of Microdem Software v. 2015.8. (developed by Peter Guth) and Global Mapper v. 15.0. This allowed examination of the accuracy of the current geological maps. LiDAR-based geomorphometric analysis was also made.

\section{TECTONICS OF THE ŁĄCZNA REGION}

\section{LIPIENICA-ŁĄCZNA FAULT (LF)}

Almost the entire KB area is segmented by NW-SE-oriented and minor ENE-WSW-trending faults. The Cretaceous rocks of the KB, Triassic outcrops of the Czarna Struga Valley, and the surrounding hills (Mielna and Dziób) are cut by the LF that continues also to the NW of the KB within the Permian volcanic rocks of the IS (Krucze Mts.). The vicinity of this fault is not well-exposed, thus especially cartographic and geomorphological evidences of faulting can be observed. The LF dips steeply to the north-east and the maximum postulated throw on the fault reaches $30 \mathrm{~m}$ (Jerzykiewicz, 1971; Don et al., 1981). In the northern part of the study area, the tectonic contact between siliceous mudstones and older sandstones of Cenomanian age indicates amplitude of $\sim 23 \mathrm{~m}$ within this fault segment (locality no. 1).

Several geomorphic evidences of tectonic activity along the LF were identified, especially during field investigations and geomorphometric analysis based on LiDAR data. To the north, they include, e.g., splitting valleys (loc. 2) formed above two segments of NNW-SSE-trending faults. The eastern segment of the LF strikes obliquely to the main fault intersection trace. Exposures of glauconitic mudstones constitute in this case part of a northeastward tilted, wedge-shaped block bounded by fault splays. On the southeastern slope of Drogosz Hill, the LF diverges into two linkage fault segments (loc. 3 ). The northwestern branch of this fault, especially on the northern slopes of Drogosz Hill, was interpreted earlier as the main fault zone of the LF (Berg and Dathe, 1905/1906) and as the "Southern Marginal Flexure Fault" (Jerzykiewicz, 1971). Detailed mapping of this area has shown that the northern, fault-affected slopes of Drogosz Hill are covered by a landslide colluvium (loc. 4; Kowalski, 2017). The surface of rupture of this landslide probably coincides with the upper part of a listric-shaped fault plane (Kowalski, 2017). Moreover, the area between the synthetic fault splays represents a relay ramp structure (loc. 3; e.g., Pea- 


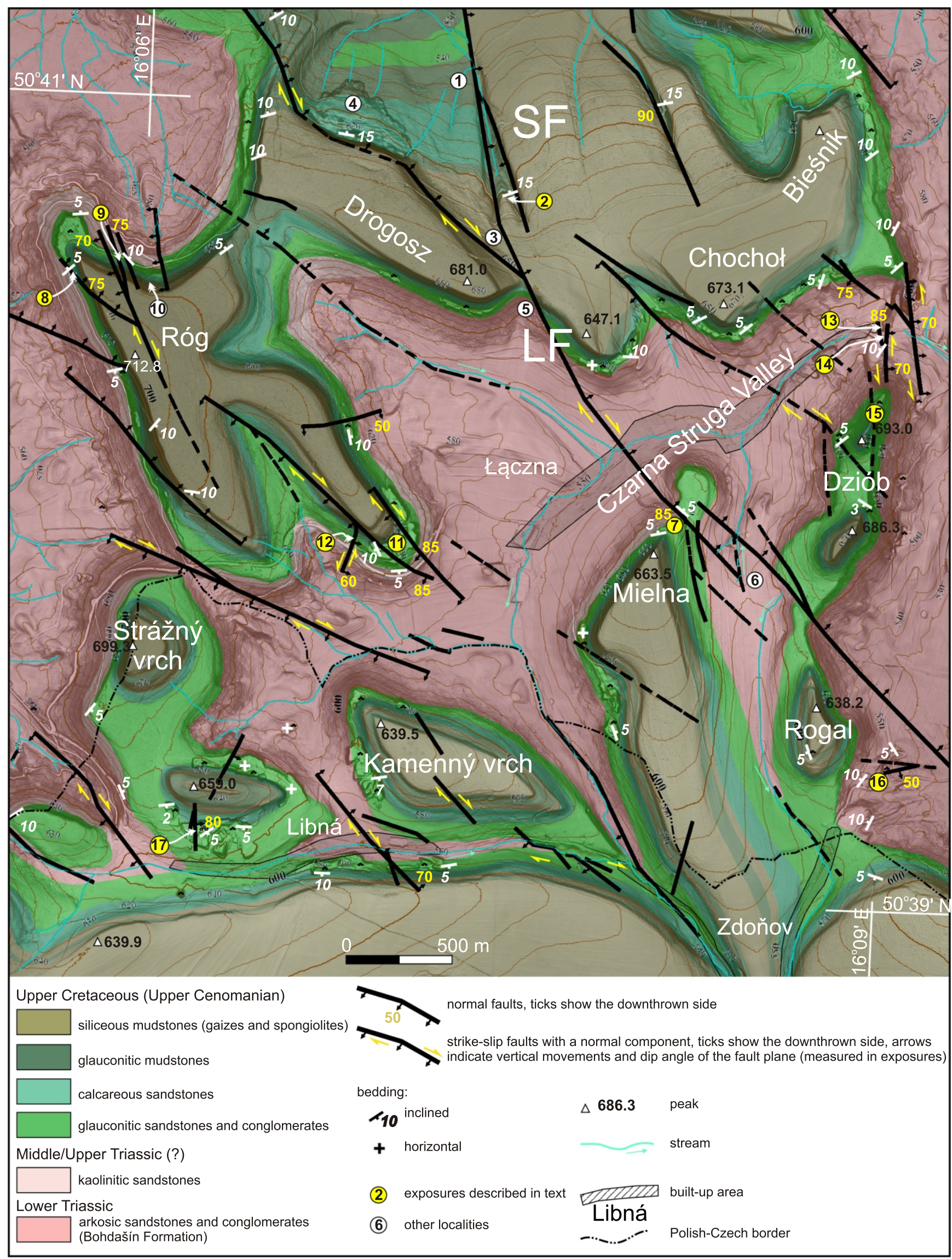

Fig. 3. Detailed geological map superimposed on a LiDAR DTM showing the main structural features of the Łączna area (author: A. Kowalski)

SF - "Southern Marginal Flexure"; other explanation as in Figure 1; contours generated from LiDAR data (interval $10 \mathrm{~m}$ ) 
Location and features of major faults and fault zones observed in the exposures from the Łączna region

\begin{tabular}{|c|c|c|c|c|c|}
\hline Locality (no.) & $\begin{array}{l}\text { Stratigraphy and } \\
\text { lithology }\end{array}$ & Coordinates & Fault geometry & $\begin{array}{l}\text { Fault plane } \\
\text { orientation }\end{array}$ & $\begin{array}{l}\text { Kinematic indicators and } \\
\text { other diagnostic structures }\end{array}$ \\
\hline N Chochoł (2) & UC; G\&SM & $\begin{array}{r}50^{\circ} 41^{\prime} 01.65^{\prime \prime} \mathrm{N} \\
16^{\circ} 08^{\prime} 02.65^{\prime \prime} \mathrm{E} \\
\end{array}$ & strike-slip, normal fault & $100 / 70$ & $\mathrm{D}, \mathrm{S}, \mathrm{R}^{\prime}$ \\
\hline N Mielna (7) & UC; GS & $\begin{array}{r}50^{\circ} 39^{\prime} 56.62^{\prime \prime} \mathrm{N} \\
16^{\circ} 08^{\prime} 05.77^{\prime \prime} \mathrm{E}\end{array}$ & strike-slip, normal fault & $280 / 85$ & $H, R^{\prime}$ \\
\hline NW Róg (8) & UC, MT; KS, GS & $\begin{array}{r}50^{\circ} 40^{\prime} 31.81^{\prime \prime} \mathrm{N} \\
16^{\circ} 05^{\prime} 43.14^{\prime \prime} \mathrm{E} \\
\end{array}$ & strike-slip, normal faults & $40 / 80$ & $\mathrm{D}, \mathrm{H}, \mathrm{R}^{\prime}, \mathrm{S}$ \\
\hline N Róg (9) & UC, MT; KS, GS & $\begin{array}{r}50^{\circ} 40^{\prime} 35.04^{\prime \prime} \mathrm{N} \\
16^{\circ} 05^{\prime} 55.14^{\prime \prime} \mathrm{E}\end{array}$ & strike-slip, normal faults & $240 / 80$ & $B, D, P, R$ \\
\hline S Róg (11) & UC; GS & $\begin{array}{r}50^{\circ} 39^{\prime} 51.80^{\prime \prime} \mathrm{N} \\
16^{\circ} 07^{\prime} 01.43^{\prime \prime} \mathrm{E} \\
\end{array}$ & strike-slip, normal faults & $240 / 85$ & $\mathrm{D}, \mathrm{H}, \mathrm{P}, \mathrm{R}, \mathrm{R}^{\prime}$ \\
\hline SW Róg (12) & UC; GS & $\begin{array}{r}50^{\circ} 39^{\prime} 53.73^{\prime \prime} \mathrm{N} \\
16^{\circ} 06^{\prime} 52.52^{\prime \prime} \mathrm{E}\end{array}$ & strike-slip, normal faults & $230 / 85$ & $D, E, R$ \\
\hline E Łączna (13) & LT; KS & $\begin{array}{r}50^{\circ} 40^{\prime} 28.44 " \mathrm{~N} \\
16^{\circ} 08^{\prime} 56.21^{\prime \prime} \mathrm{E} \\
\end{array}$ & strike-slip; normal faults & $\begin{array}{l}282 / 85 \\
80 / 80 \\
\end{array}$ & $\mathrm{H}, \mathrm{R}$, S, D, Fe \\
\hline Samotna (14) & LT; KS & $\begin{array}{l}50^{\circ} 40^{\prime} 26.40^{\prime \prime} \mathrm{N} \\
16^{\circ} 08^{\prime} 58.45^{\prime \prime} \mathrm{E}\end{array}$ & strike-slip faults & $90 / 55$ & $E, S$ \\
\hline N Dziób (15) & UC; GS & $\begin{array}{l}50^{\circ} 40^{\prime} 11.10^{\prime \prime} \mathrm{N} \\
16^{\circ} 08^{\prime} 48.80^{\prime \prime} \mathrm{E} \\
\end{array}$ & strike-slip fault & $100 / 85$ & $\mathrm{R}, \mathrm{S}$ \\
\hline Zdoňov 1 (16) & LT; KS & $\begin{array}{l}50^{\circ} 39^{\prime} 19.98^{\prime \prime} \mathrm{N} \\
16^{\circ} 08^{\prime} 57.85^{\prime \prime} \mathrm{E}\end{array}$ & normal fault & $170 / 50$ & $\mathrm{D}, \mathrm{Fe}$ \\
\hline Zdoňov 2 (16) & LT; KS & $\begin{array}{l}50^{\circ} 39^{\prime} 21.86^{\prime \prime} \mathrm{N} \\
16^{\circ} 09^{\prime} 02.70^{\prime \prime} \mathrm{E} \\
\end{array}$ & normal fault & $186 / 30$ & $E, U$ \\
\hline $\begin{array}{l}\text { Libná (Lev. } \\
\text { Lomy) (17) }\end{array}$ & UC; GS & $\begin{array}{l}50^{\circ} 39^{\prime} 09.43^{\prime \prime} \mathrm{N} \\
16^{\circ} 06^{\prime} 17.66^{\prime \prime} \mathrm{E}\end{array}$ & normal fault, strike-slip & $\begin{array}{l}260 / 90 \\
284 / 85 \\
\end{array}$ & $\mathrm{D}, \mathrm{G}, \mathrm{H}, \mathrm{R}, \mathrm{S}, \mathrm{U}$ \\
\hline
\end{tabular}

Stratigraphy and lithology: UC - Upper Cretaceous; MT - Middle Triassic; LT - Lower Triassic. GS - glauconitic sandstones; G\&SM glauconitic and siliceous mudstones; KS - kaolinitic sandstones. Kinematic indicators and other diagnostic structures: B - breccia; D dense fractures; $\mathrm{E}$ - en echelon cracks; Fe - iron compounds within fractures; $\mathrm{G}$ - gouge; $\mathrm{H}$ - hackles; P - polished fault surfaces; R - ridges and steps, R' - Riedel shears; S - slickensides; U - soft-sediment deformation

cock and Sanderson, 1991) that affects the local drainage pattern of the northern slopes of Drogosz Hill. A similar case is present within the southern escarpment of the Zawory Ridge, where the eastern fault block is tilted to the NE and displaced approximately $500 \mathrm{~m}$ towards the SW (loc. 5). A tilted block is associated with a relay ramp between two overstepping normal faults with a small strike-slip component (e.g., Peacock and Sanderson, 1995; Hus et al., 2005). The offset between the Cretaceous exposures indicates a ca. $20 \mathrm{~m}$ throw and a dextral strike-slip movement on this segment of the fault. Fault-related morphological and structural effects are well visible to the south of Łączna, where the northern part of Mielna and Dziób hills are dissected by the LF. Its occurrence is evidenced by poorly preserved fault scarps and a ca. $20 \mathrm{~m}$ displacement of the Lower Quader outcrops across the cuesta ridge (loc. 6; Fig. 3).

Moreover, a watershed zone was formed within the southeastern part of the LF between Mielna and Dziób hills (loc. 6). The occurrence of horsetail and low-angle Riedel shear fractures in exposures within this section of the fault indicates NW-SE-trending dextral strike-slip movements. This is also confirmed by observations of steep extension fractures with hackles (Herman, 2009) and oblique pinnate joints (Hancock, 1985; Engelder, 1989), which occur in artificial exposures of the Lower Quader on the northern slopes of Mielna Hill (loc. 7).

\section{RÓG FLOWER STRUCTURE}

NW- and NNW-trending, both strike-slip and dip-slip faults, were also recognized in the southwestern termination of the $\mathrm{KB}$. The greatest concentration of these faults is observed in ar- tificial exposures of the Lower Quader around Róg Hill - the most prominent table hill (712.8 $\mathrm{m}$ a.s.I.) within the Zawory Ridge. According to Jerzykiewicz $(1969,1971)$, the southern part of the Róg plateau is related to the axis of the Łączna Anticline.

Fault planes crop out mainly in exposures along forest roads traversing the northeastern and northern slopes of Róg Hill (hereinafter: N Róg faults). The first damage zone (loc. 8; Fig. 4A, B) comprises numerous NW-SE-trending, both dextral strike-slip and normal faults. Fault surfaces are vertical or steeply inclined at $50-90^{\circ}$ and strike obliquely to the main lithological boundaries (Fig. 3). Low-angle R-shears, hackles and slickensides observed on the fracture surfaces indicate mostly dextral strike-slip movements. The amplitude of horizontal movements is difficult to estimate here, although a precise cartographic delimitation of the Triassic-Cretaceous contact (Fig. 3) allows determining a ca. $5 \mathrm{~m}$ downthrow of the NW limb of the fault(s). To the north-east (northern slopes of Róg Hill), the azimuth of the dip direction of faults and fractures changes markedly (loc. 9). The distribution of fault planes varies between azimuth 230 and $250^{\circ}$. Sub-vertical and vertical faults are characterized by a ca. $100 \mathrm{~m}$ wide breccia zone (Fig. 4C) that comprises numerous strongly fractured blocks of sandstones, in some cases bounded by antithetic faults. Fault surfaces are generally polished, rarely striated. Dextral displacements prevail in these faults. Close to the fault planes, contractional, faulted hybrid joints (Fig. 4D; Marín-Lechado et al., 2004) can be observed. The southwestward offset of the Triassic and Cretaceous contact indicates a ca. $13 \mathrm{~m}$ vertical displacement within this fault zone. Numerous deformations are reflected in the morphological features of the slopes. Escarpments border- 

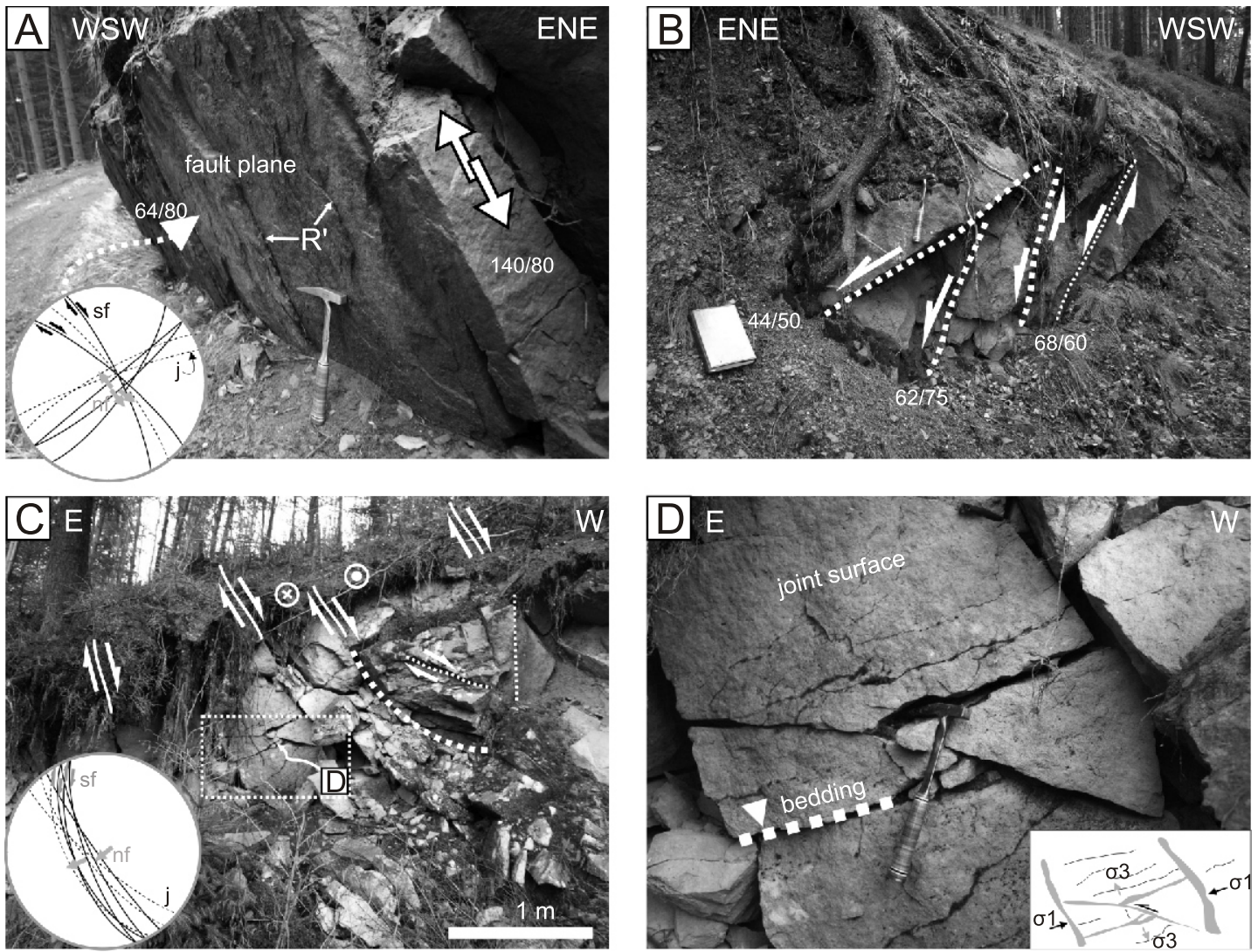

Fig. 4. Structural features of the N Róg faults

A - dextral fault (sf on the diagram) with low-angle R-shears and the perpendicular joint surface ( $j$ on the diagram) affected by normal fault (nf on the diagram) - western limb of the Róg Flower Structure (loc. 8); B - set of normal faults with a strike-slip component - western limb of the Róg Flower Structure (loc. 8); C - breccia zone within the western limb of the Róg Flower Structure (loc. 9), the symbols $\otimes$ and $\odot$ show motion between blocks bounded by strike-slip faults: away and toward an observer, respectively; D - contractional faulted hybrid joints within the breccia zone (loc. 9)

ing the Róg plateau are cut by narrow, rectilinear, $\mathrm{N}-\mathrm{S}$ and NNW-SSE-trending deep valleys (loc. 10), whose formation was probably induced by a large concentration of fractures within brittle shear/fault zones.

Similarly to the N Róg faults, brittle deformations, which crop out in the southern part of the Róg plateau (Fig. 3), show a NNW-SSE trend $(320 \pm 340)$, with fault dips ranging within $80-90^{\circ}$ (loc. 11). Vertical fault planes were observed in several abandoned quarries of the Lower Quader. Characteristics of the fault planes and their orientation similar to that of the regional system of extensional fractures indicate that the fault zones are strictly related to joints (Fig. 5A, C, G). Some of the vertical NNW-SSE-trending joints with a maximum spacing of $30 \mathrm{~cm}$ consist of packages of intensely sheared and deformed sandstones (Fig. 5E). They should be referred to as tensile cracks reactivated as cataclastic shear zones (e.g., Pluijm and Marshack, 2004). Fracture surfaces are visibly affected by low-angle, short R-shear fractures (Fig. 5F), hackles and en echelon cracks (Fig. 5B), which indicate dextral movements with a normal component. Most of these faults led to a change in the orientation of Cretaceous strata (cf. Fig. 3).

Fault surfaces, contrary to the N Róg strike-slip and normal faults, are usually striated (Fig. 5A) and display the presence of asymmetric steps, ridges (Fig. 5D) and slickensides (Fig. 5A). In addition, plumose structures can be observed on adjacent joint surfaces (Fig. 5G). Nearly vertical strike-slip faults are strictly associated with listric or nearly planar normal faults and their splays (Fig. 5D) that form conjugate fault sets. Listric faults trend mainly parallel, less oblique to the strike-slip fault planes (Fig. 5F). In a small abandoned quarry (loc. 12) located to the west of the previously described exposures, en echelon fault-arrays were recognized. They are related to left-step, strike-slip faults determined also by cartographic methods. In this quarry, the sandstones are strongly fractured, which was probably the main reason of its abandonment.

The fault pattern and their kinematics indicate that several splay and en echelon faults formed a negative flower structure that runs in a NNW-SSE direction across the Róg table mountain (Fig. 6)

\section{OTHER EVIDENCES OF FAULTING IN THE ŁACZNA REGION}

Apart from the major faults described above, several minor faults and fault zones were identified in the Łączna area. They are manifested in the morphology of the valleys and ridges and exposed in numerous quarries and natural exposures surrounding the highest hills of the region. Distinct evidence of faulting was found within the Buntsandstein exposures in the western termination of the Czarna Struga Valley, between Dziób and Chochoł hills. In a small quarry located to the north of the road connecting the villages of Różana and Łączna, nearly vertical NNW-SSE-trending joint sets and extension fractures linked with normal faults can be observed. Strongly fractured sandstones occur in the eastern part of the quarry (loc. 13; 

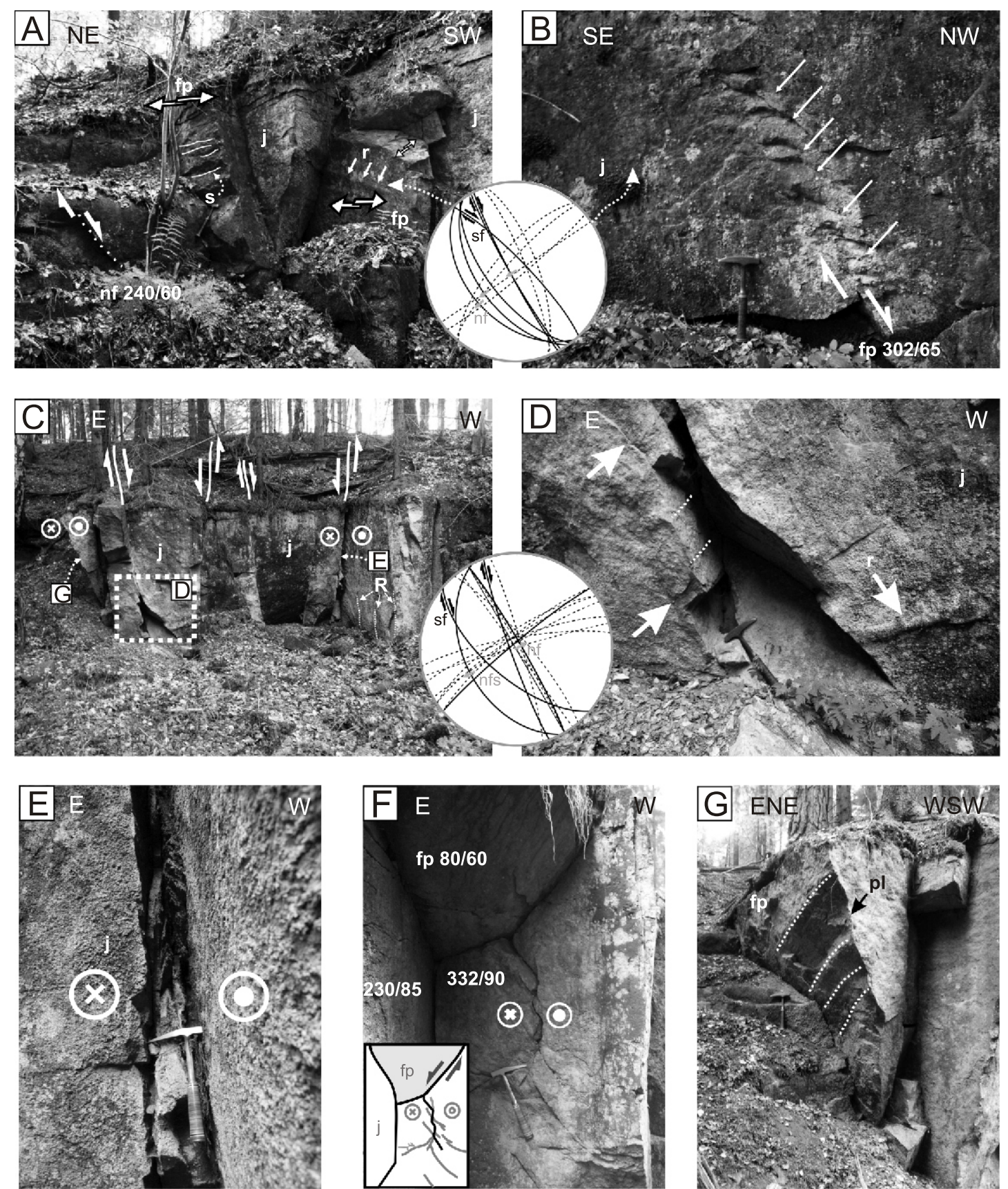

Fig. 5. Structural features of the S Róg faults (Lower Quader exposures, loc. 11)

A - nearly vertical planes of strike-slip faults (fp, sf on the diagrams) with visible slickensides (s) and ridges ( $r$ ); note the SW-dipping normal fault (dotted line) linked with strike-slip deformation; B - en echelon cracks associated with normal fault; C - set of normal- and dextral strike-slip faults associated with joints (j); low-angle R-shears (R) are visible and indicate dextral sense of movements; D - fault splays (= secondary faults; marked with arrows) associated with strike-slip fault (slickensides marked with dotted lines), perpendicular joint surface (j) affected also by strike-slip fault with ridges ( $r$ ); $\mathbf{E}$ - cataclastic shear zone between vertical joint surfaces; $\mathbf{F}$ - dextral strike-slip fault with associated fractures and oblique normal, listric-shaped fault (fp); G - part of a plumose structure (pl) on nearly vertical plane (fp) of strike-slip fault; other explanations as in Figure 4

Fig. 7A). Fractures are related to the N-S and NNW-SSE-oriented sinistral strike-slip faults that cause a change in orientation of arkosic sandstones. The orientation of these fractures strongly coincides with the elongation of well-preserved tors (Samotna, Bliźniaczki and Czartowskie Skały groups) on the convex slopes of Dziób and Chochoł hills (Fig. 3; loc. 14). On the eastern wall of the Samotna tor (Fig. 7B) occur left-step- ping, en echelon cracks and low-angle R-shears. Low-angle fractures and slickensides were recognized also on the steep walls of the Czartowskie Skały group. Tectonically affected tors form N-S-oriented ridges (Dziób and Rogal hills), which are perpendicular to the axis of the Czarna Struga Valley and emphasize the structurally controlled local watershed zone between the Nysa Kłodzka and Metuja River basins. 


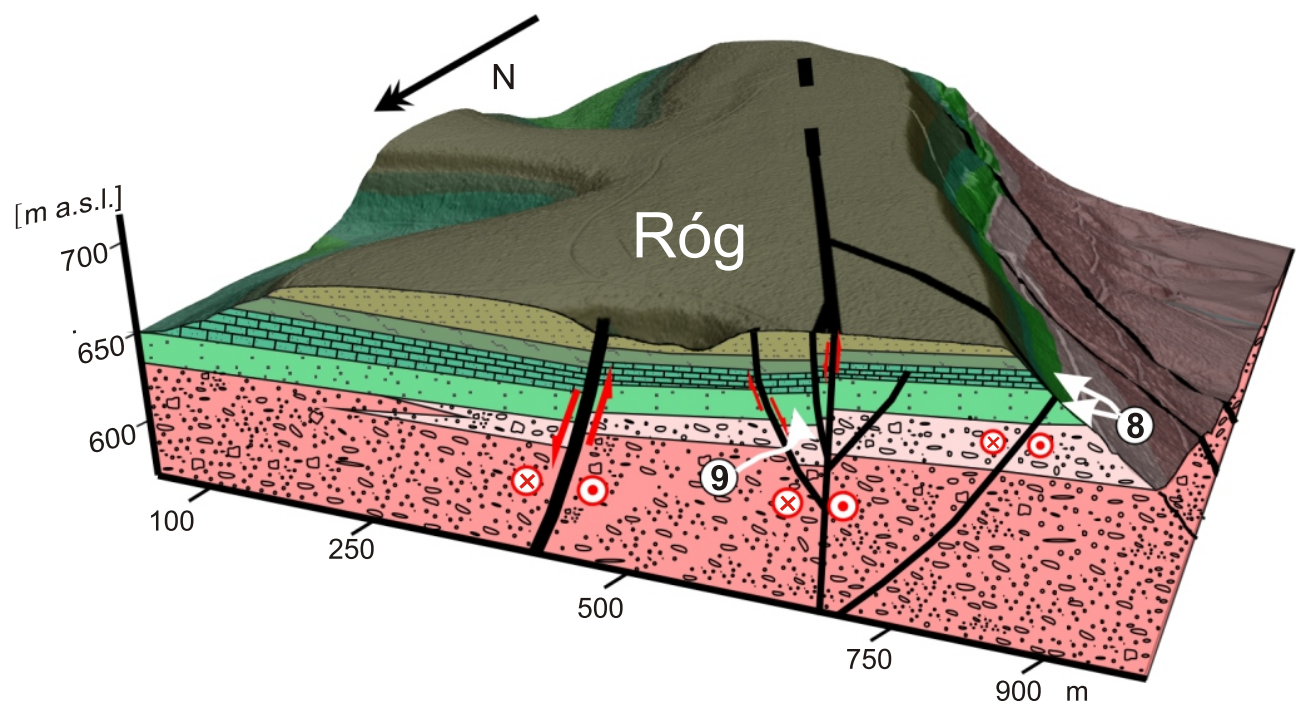

Fig. 6. Block diagram of the northern part of the Róg Flower Structure (vertical exaggeration 1.5)

Geology and localities according to Figure 3; explanations as in Figure 4
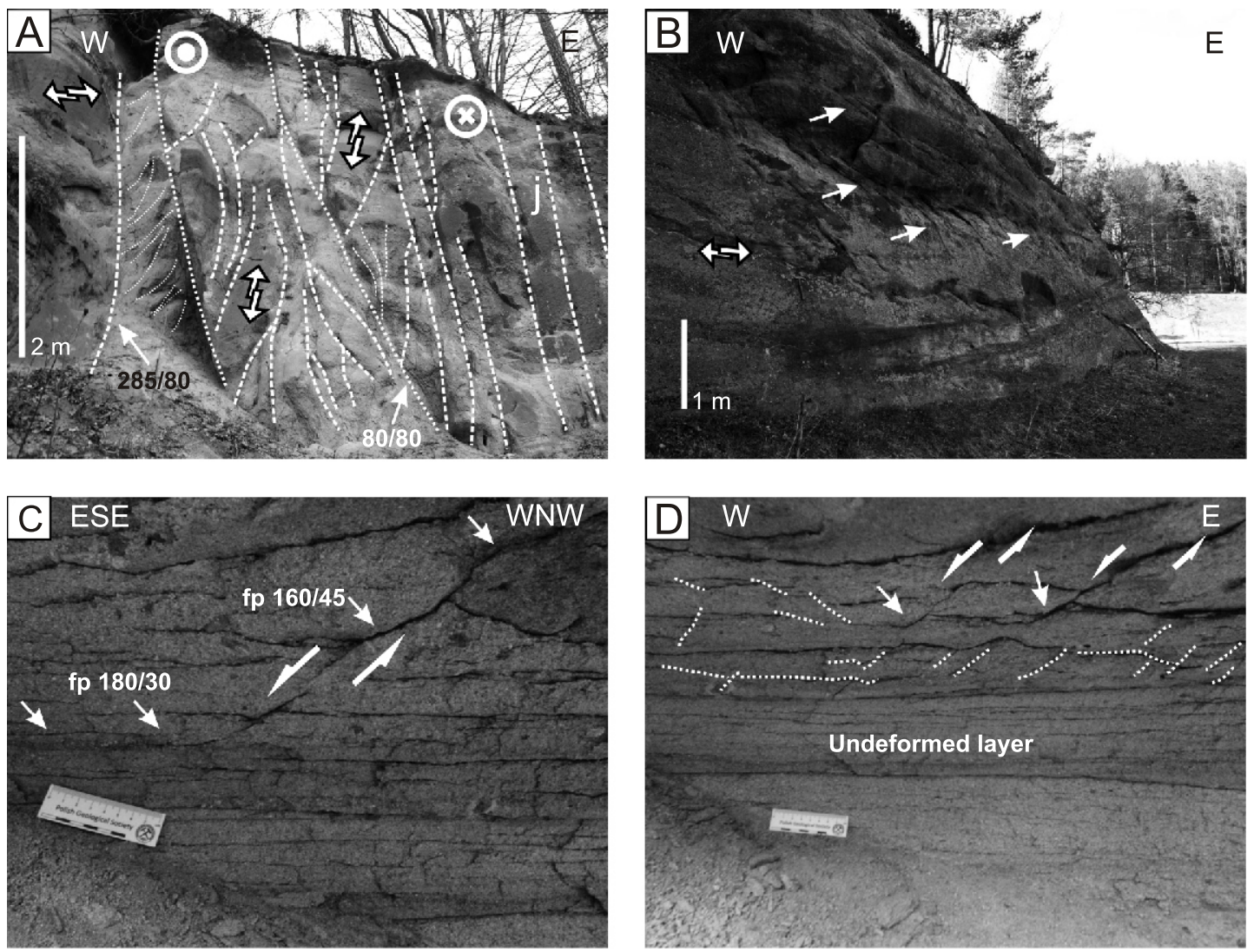

Fig. 7. Deformations within arkosic sandstones (Buntsandstein)

A - sinistral strike-slip faults in an abandoned quarry (E Łaczna, loc. 13); B - left-stepping en echelon cracks and R-shears on the tor surface (Samotna - loc. 14); C - low-angle listric fault (fp); D - synsedimentary microfaults and cracks (marked with arrows and dotted lines) within coarse-grained sandstones; lower part of layer is undeformed (loc. 16); other explanations as in Figure 4 
The N-S-trending ridge of Dziób Hill, untypical for this area, is bounded by steep escarpments $\left(40^{\circ}\right)$ and constitutes probably the prolongation of this displacement zone (Fig. 3). It is also confirmed by poorly exposed cataclasites and fault breccias that occur within the Lower Quader exposures of the northern slopes of Dziób hill (loc. 15).

Several meso-scale deformations were also recognized in the Buntsandstein exposures near Zdoňov (loc. 16). They include, for example, low-angle listric faults with a throw up to $\sim 0.5 \mathrm{~m}$ (Fig. 7C) and synsedimentary microfaults with a few centimetres throw (Fig. 7D).

Several mesofault planes and deformation structures were also observed in abandoned quarries of the Lower Quader in the Czech part of the study area, especially in the Libná region. In periodically active pits ("Levobřežní lomy u Libné”; loc. 17) situated on the southern slopes of an unnamed hill (659 m a.s.l.; Fig. 3), distinct fault mesostructures were observed. Similarly as in the N Róg faults, the fault planes are mainly vertical, N-S-trending and strictly coinciding with orthogonal joints (Fig. 8). Damage zones related to normal- and strike-slip faults contain clay gouges that developed within brittle shear zones. Features of fault planes (striated ridges, slickensides and grooves) indicate dextral movements between sandstone blocks.

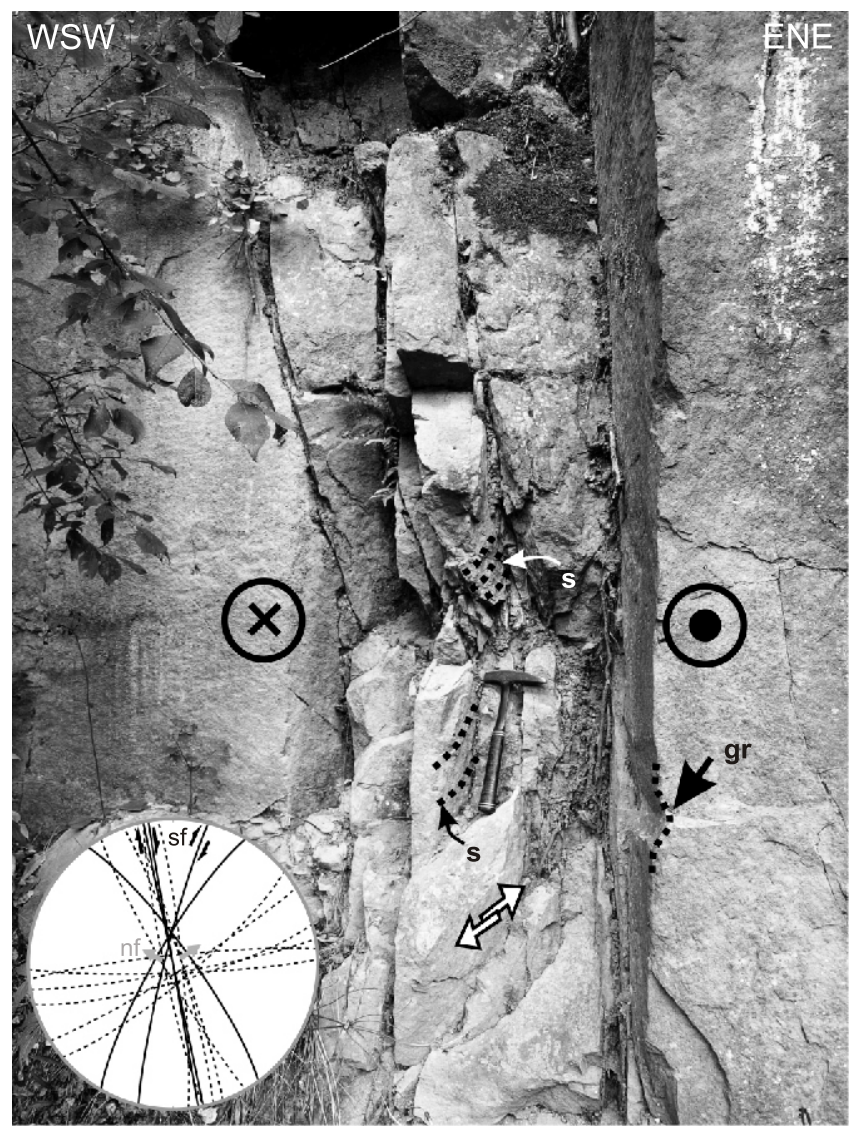

Fig. 8. Damage zone consisting of normal and dextral strike-slip faults in the Libna region (“Levobřežní lomy u Libné”, loc. 17)

Note cataclasites and gouge between conjugate, vertical and sub-vertical faults with visible slickensides (s) and grooves

(gr) on the fault planes; other explanations as in Figure 4

\section{KAOLINITIC SANDSTONES - DISTINCT HORIZON WITHIN THE INTRASUDETIC SYNCLINORIUM}

Kaolinitic sandstones occur only locally in the topmost part of the Bohdašín Formation. In the study area, they were recognized in exposures on the western slopes of Róg Hill, on the southern slopes of Drogosz Hill and on the western slopes of Strážný Vrch and Mielna hills (Fig. 3). In the Krzeszów Brachysyncline, kaolinitic sandstones were also documented in abandoned quarries located near Jawiszów and Krzeszów (Góra Świętej Anny locality). Despite the fact that artificial exposures of kaolinitic sandstones are small and limited only to road crosscuts in the study area, narrow exposures of these sediments are highlighted by the occurrence of distinct kaolinitic soils with dispersed pebbles. Results of geological mapping suggest that the preserved thickness of the kaolinitic sandstones is between 10 and $15 \mathrm{~m}$ (Fig. 3).

Kaolinitic sandstones (Ger. Weißer Kaolinsandstein) were marked as a separate lithological unit on the first detailed geological map of the Łączna region by Berg and Dathe (1905/1906), and assigned to the Middle Buntsandstein. Mroczkowski (1977) assumed that they might constitute a relic of an ancient weathering cover developed at the top of the Buntsandstein deposits from the Early Triassic to the Late Cenomanian. Don et al. (1981) marked these sediments also on top of Buntsandstein arkosic sandstones in the Róg area and speculated that they might represent Lower Triassic sediments that were reworked during the Late Cretaceous marine transgression. According to Prouza et al. (1985), the kaolinitic sandstones that crop out in the Zawory Ridge are lithologically similar to the Devět křižů sandstones (Holub, 1966) described in detail by Uličný (2004) and Wojewoda et al. (2016). The Devět křižů sandstones are exposed in the close vicinity of the southwestern boundary of the Intrasudetic Synclinorium (the Hronov-Poŕíći Fault Zone HPFZ, cf. Fig. 1), within the morphological elevation between the Náchod and Trutnov basins (Wojewoda et al., 2016). Both the origin and age of these deposits remain controversial (see: Geological Setting), although based on regional stratigraphic subdivisions and the lithological similarity to the kaolinitic sandstones from the adjacent North Sudetic Synclinorium area, they are probably late Early or early Middle Triassic in age (Chrząstek, 2002).

In the lower part of the succession, kaolinitic sandstones are represented by coarse-grained, weakly lithified and strongly kaolinised arkosic wackes. Towards the top of the profile, sandstones are whitish to light grey and reveal distinct platy parting, which is usually bedding-parallel. They represent moderately to well-sorted, medium- and coarse-grained, sub-lithic and sub-arkosic arenites. Most of framework grains range from 0.5 to $0.8 \mathrm{~mm}$, rarely $1 \mathrm{~mm}$ in size (Fig. 9). Based on the classification of Pettijohn (1975), the grains are usually sub-angular, intermittently sub-rounded and rounded. Monocrystalline quartz is the major mineral component of these deposits. Its content varies between 70 and $80 \%$. Strongly fractured and kaolinised feldspar grains constitute up to $10 \%$ of the framework grains. Lithic fragments are represented by metamorphic (mostly gneisses and quartzites) and igneous rocks (granites, granodiorites, rarely rhyolites), which are also affected by kaolinisation processes. Most of the lithic grains, probably remnants of mica schists, are strongly sericitised and kaolinised. The sandstone matrix is composed of kaolinite-group minerals with a small admixture of illite. 

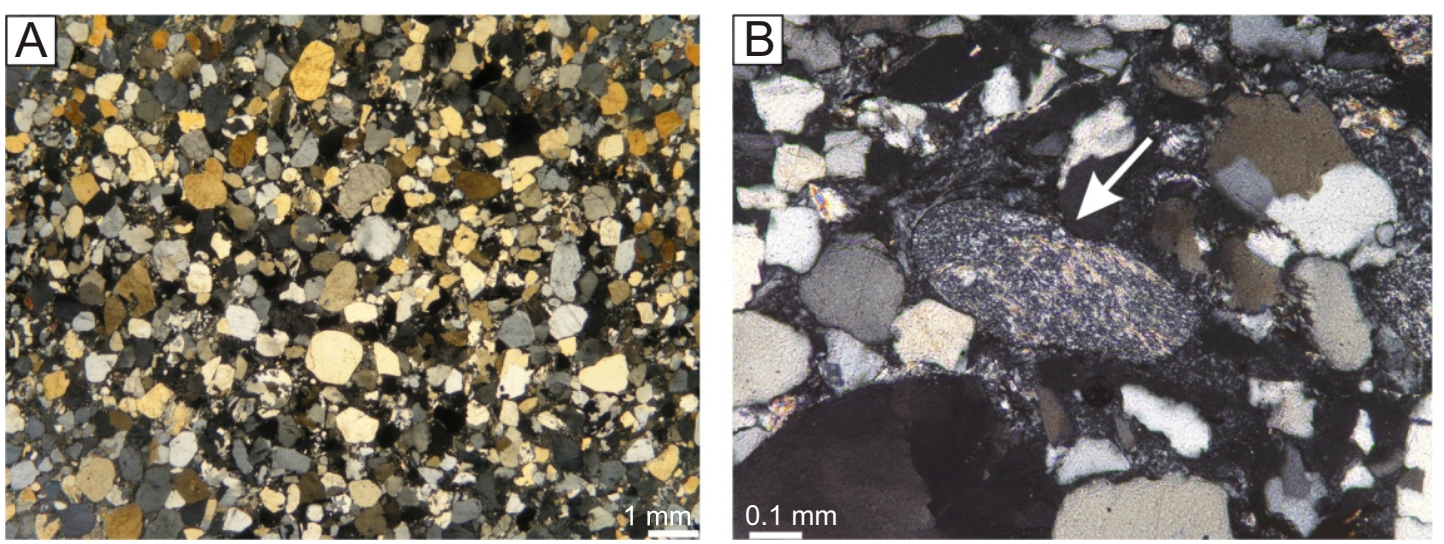

Fig. 9. Kaolinitic sandstones in a thin section (A; crossed polars), note strong kaolinisation of the matrix and lithic fragments; on the microphotograph to the right (B; crossed polars): strongly kaolinised and sericitised grain of igneous rock, marked with arrow

Jerzykiewicz (1971) and Mroczkowski (1977) argued that the topmost part of the Bohdašín Formation is represented by massive coarse-grained sandstones. The results of field investigations did not confirm this opinion (Fig. 10). Kaolinitic sandstones show different types of structures that vary within the vertical succession. Structural features of the lowermost part of the kaolinitic sandstones are similar to the sandstones from the lower and middle part of the Bohdašín Formation. They are represented mostly by cross-stratified sandstone and conglomerate facies, interpreted as braided river channel-fill deposits (Prouza et al., 1985; Fig. 10A). Individual beds of these facies are 1-2 $\mathrm{m}$ thick and show a fining-upward pattern. The lower boundaries of the beds are marked by scoured, erosional surfaces overlain by thin $(0.1-0.3 \mathrm{~m})$ conglomeratic layers. Conglomerates usually pass upward into medium- and large-scale, trough- and planar-stratified sandstones with dispersed pebbles. Overbank deposits are less abundant and represented by parallel-laminated silty-clayey intercalations ranging from 0.05 to $0.2 \mathrm{~m}$ in thickness.

The upper part of the kaolinitic sandstones consists of large-scale cross-bedded strata ("slab sandstones"). The lower boundary of these deposits is marked by a thin, $\sim 0.1 \mathrm{~m}$ thick conglomerate bed that contains strongly kaolinised pebbles of metamorphic and igneous rocks up to $6 \mathrm{~cm}$ in size. Conglomerates pass upward into cross-stratified sandstones. Individual beds range between 0.1 and $0.2 \mathrm{~m}$ in thickness and are inclined up to $\sim 5^{\circ}$ towards the north and north-west (Fig. 10B, D). The bedding boundaries are marked by grain-size changes. In a small exposure on the western slopes of Strážný Vrch Hill, medium-grained kaolinitic sandstones display small-scale, symmetrical ripple-lamination within large-scale bedded strata Symmetrical, partly bifurcated ripples occur on top of the bedding surfaces (Fig. 10C). Medium-scale trough-stratification is also common, especially in small tors in the northern part of Róg Hill (Fig. 10B). They are restricted to the topmost part of the kaolinitic sandstones and were observed only $\sim 0.5 \mathrm{~m}$ below the Triassic/Cretaceous unconformity. It is worth mentioning that intercalations of strongly bioturbated coaly mudstones occur within kaolinitic sandstones in the northern part of the KB near Krzeszów (Góra Świętej Anny locality; Fig. 11; Jerzykiewicz, 1971; Kowalski, 2016).

\section{DISCUSSION AND SUMMARY}

The geometry and kinematics of major deformation structures cutting the study area indicate mainly a normal and dextral strike-slip component of the movements. The oldest deformations of the area include pre-lithification (synsedimentary) faults and fissures, which were formed due to NE-SW tension and coincide with the orientation of the youngest brittle deformation structures: joints, normal faults and strike-slip faults. NNW-SSE-oriented joints developed presumably as opening mode (mode I) fractures (Pollard and Aydin, 1988) that are parallel to the $\sigma 1$ axis and perpendicular to the maximum tensile stress (Ramsay, 1980). The problem of joints formation within the IS has not been examined in detail so far and their compressional origin cannot be excluded. However, many authors consider that joints formed in an extensional setting (Jerzykiewicz, 1968; Stejskal et al., 2012; Wojewoda, 2012). Well-exposed plumose structures and hackles occurring on the joint surfaces confirm this view and their tensile origin (cf. Mierzejewski, 2015). Significant changes in the joint orientation are caused by shearing along joint surfaces (Wilkins et al., 2001; Myers and Aydin, 2004), which produced fractures and fault planes oblique to the pre-existing joints. Hence, most of the observed fault planes should be classified as reactivated joints ("faulted joints"; Wilkins et al., 2001). Shearing of joints is confirmed by numerous NNW-SSE-trending vertical strike-slip and normal faults, which are parallel and sub-parallel to the joint surfaces. ESE-WNW-oriented systematic sets of joints, perpendicular to the joints described above, were also reactivated with a small normal component. Short low-angle R-shears and en echelon fractures, recognized in the study area, have been formed obliquely to the strike-slip faults and suggest permanent dextral movements occurring in a transtensional setting. Sinistral displacements occurring in exposures to the east of Łączna represent high-angle R'-shears, antithetic to the main, NW-SE-trending dextral strike-slip faults. Contractional structures comprise only faulted hybrid joints (Marin-Lechado et al., 2004), formed due to local compression within the negative flower structures. 

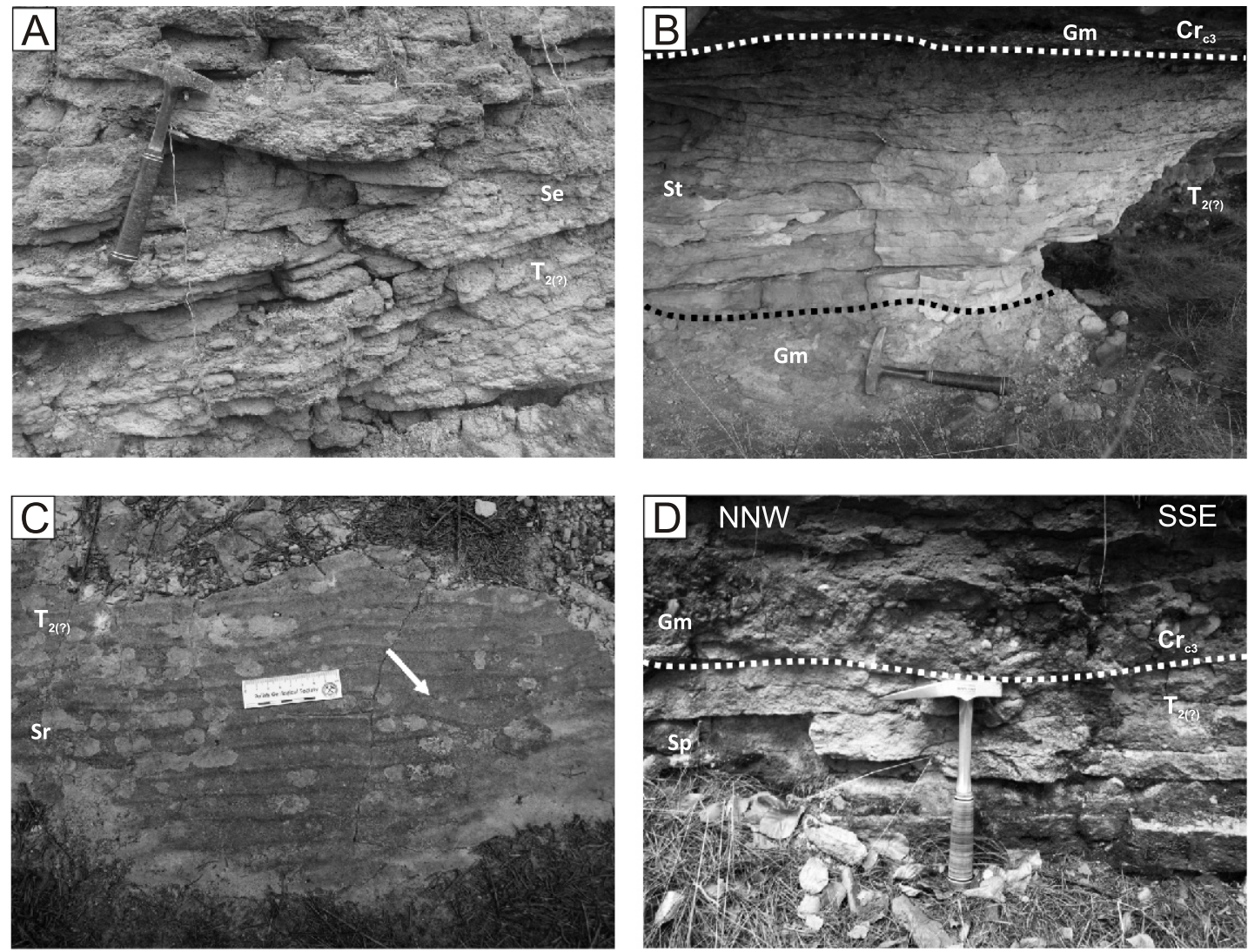

Fig. 10. Structural features of kaolinitic sandstones

A - strongly weathered and kaolinised channel-fill deposits (Se) in the lower part of the profile; $\mathbf{B}$ - medium-scale trough-stratification (St) within kaolinitic sandstones overlain by Upper Cenomanian basal conglomerates $(\mathrm{Gm})$, note the layer of conglomerates $(\mathrm{Gm})$ underlying the "slab sandstones" in the lower part of the exposure; C - symmetrical (Sr), partly bifurcated ripples (bifurcations marked with arrow) on the top of the bedding surface; D - erosional boundary between large-scale, planar-stratified (Sp) kaolinitic sandstones and glauconitic sandstones (western slopes of Róg Hill, loc. 8), note that the erosional surface is marked by a bed of basal conglomerates $(\mathrm{Gm})$

Structural analysis has shown that the Łączna Anticline area displays distinctive structural, morphological and lithological features typical of intrabasinal elevated areas bounded by extensional strike-slip and normal faults. The southern branch of the LF and the oblique faults constitute the principal displacement zone (PDZ; Christie-Blick and Biddle, 1985) that subdivides this part of the IS into two rhomb-shaped, half-graben units with distinct subsidence centres (Fig. 11). The PDZ is associated with negative flower structures (Róg Flower Structure) to the west and normal- and strike-slip faults to the east. The LF affected the development and geometry of the entire KB area. This is confirmed by differences in total vertical displacements on this fault observed within the KB and LA, which are $\sim 40-50 \mathrm{~m}$ within the $K B$ and $20-25 m$ within the LA.

Kaolinitic sandstones constitute a distinct horizon in the northern part of the IS. Their distribution is strictly related to tectonic zones that occur within the southern limb of the KB and is also limited to a morphological elevation (Zawory Range). Moreover, kaolinitic sandstones do not occur below the Cretaceous deposits in adjacent, present-day basin structures, which is confirmed by borehole data (Wojtkowiak et al., 2011). During the Early Triassic, the KB and PB constituted a sedimentary basin with a single, central depocentre formed above the strike-slip fault (Fig. 11A). This is confirmed by Early Triassic and even Permian palaeogeographic reconstructions offered by Mroczkowski (1977) and Śliwiński (1981). Permanent transtension of the basin basement resulted in the formation of dual-depocentre geometries (Dooley and Schreurs, 2012) within the interior of a pull-apart basin (the KB in this case, Wojewoda, 2007). During late Early and probably Middle Triassic times, the southwestern and northeastern terminations of the KB constituted narrow basin depocentres separated by an elongated, NW-SE-oriented elevation (Fig. 11B). This process is well-documented by analogue modelling of transtensional basins (Wu et al., 2009). Probably in the late Early Triassic, strongly kaolinitic, regolith-type weathering covers developed on the sandstones of the Bohdašín Formation. The regolith succession in the topmost part of the sandstones developed without disintegration of their primary structure. It is documented by sedimentary structures observed in the lowermost part of the kaolinitic sandstones succession, similar to the Buntsandstein deposits. Strong kaolinisation of the uppermost part of the Buntsandstein deposits was claimed by many authors (Jerzykiewicz, 1971; Mroczkowski, 1977; Don et al., 1981). During the Early to Middle Triassic, the KB region was a flat plain area periodically flooded by a shallow sea (Wojewoda et al., 2016). A conglomerate bed in the bottom of the "slab sandstones" is interpreted herein as a transgressive deposit. Small-scale, wave-ripple lamination observed on the bedding surfaces of kaolinitic sandstones shows that the depth of individual, probably isolated water bodies, did not exceed a few decimetres. It is therefore quite probable that the local depressions were occupied by shallow ephemeral salt lakes. The playa-like depressed area was occasionally cut by narrow river 


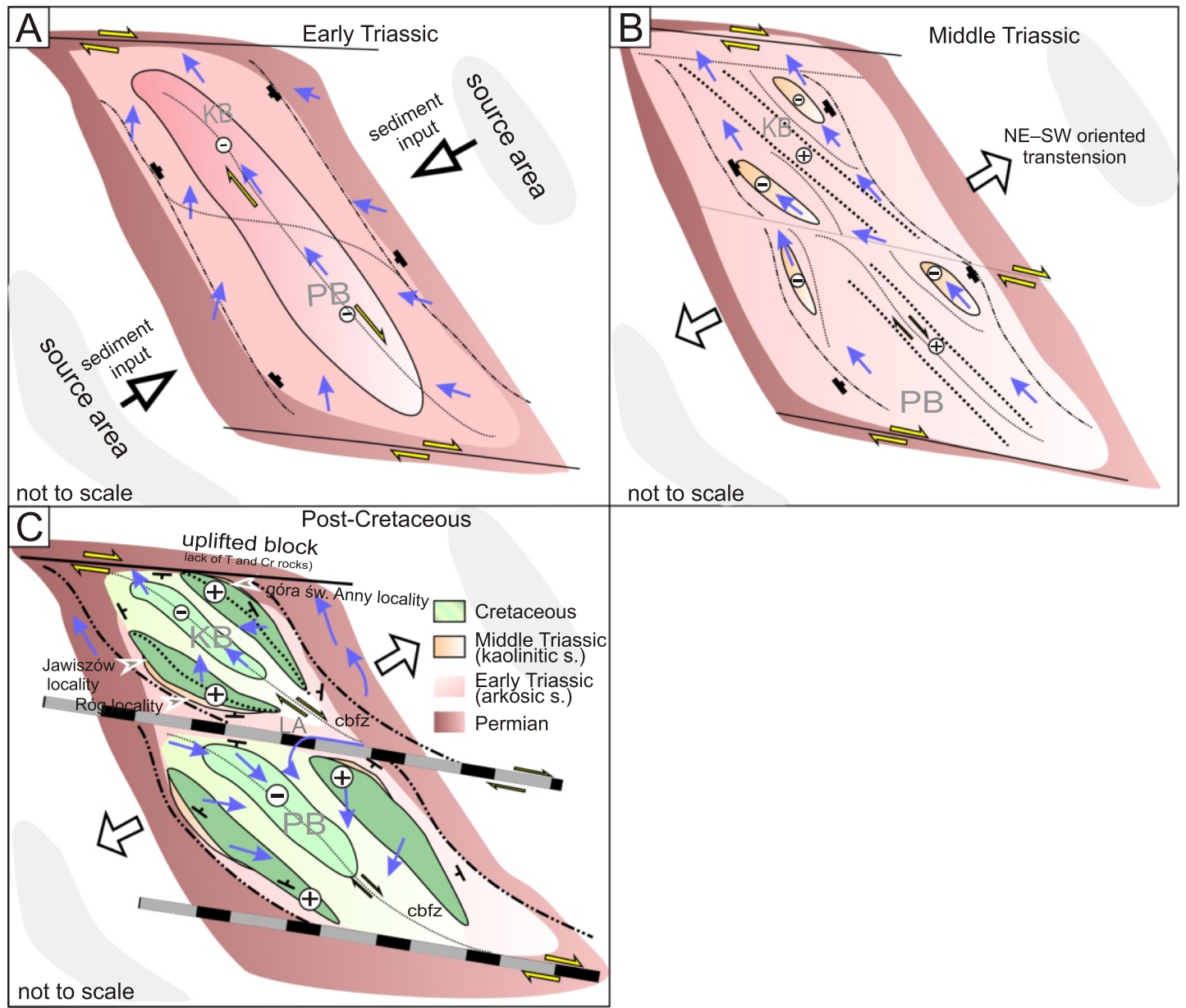

Fig. 11A-C - schematic evolution of the Łączna Anticline area

Ellipsoids indicate depocentres (-) and elevations (+) during Triassic and post-Cretaceous times; blue arrows indicate flow directions; other explanations as in Figure 1

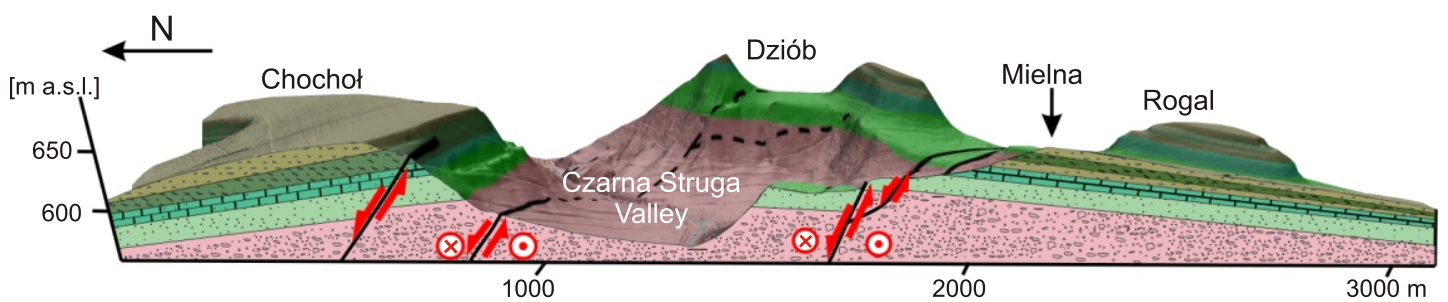

Fig. 12. Block diagram of the Łączna Anticline showing changes in dip angles caused by strike-slip and normal faulting that produce visual and apparent effects of anticlinal bend

Geology according to Figure 3

channels. This is documented by shallow erosional scours within the kaolinitic sandstones. Strongly bioturbated coaly mudstones that occur within the kaolinitic sandstones in the vicinity of Krzeszów (Jerzykiewicz, 1971) represent salt marsh environment deposits (Kowalski, 2016) linked with a shallow sea transgression. After regression and a long period ( 140 My) of denudation, in the Late Cretaceous (Late Cenomanian), the study area was flooded by a shallow epicontinental sea. At that time, the KB area was a flat, low-lying peneplained land built of older sedimentary rocks (Wojewoda, 1997; Uličný, 2004). Preservation of kaolinitic sandstones below the transgressive Upper Cenomanian clastic deposits was possible only within local structural depressions near Łączna and Krzeszów.

Regional palaeogeographic reconstructions and structural analysis conducted in the KB and LA areas reflect general consistency and permanent geodynamic development of this area in a transtensional strike-slip setting. Presented results of the structural and sedimentological studies do not coincide with palaeo- and recent stress reconstructions proposed by Nováková (2014) and Prouza et al. (2015) for the western border of the Police Brachysyncline (the HPFZ). According to these authors, the HPFZ and adjacent fault zones consist of inverse faults and even gently dipping thrusts, associated with 
pop-up structures (Kozdrój and Cymerman, 2003). Apart from the results of structural analysis conducted only in a few individual localities (Cymerman, 1999; Nováková, 2014) there are no evidences of thrust faulting in the IS area. Moreover, distinct faults and fault zones within the IS (e.g. HPFZ) were interpreted by different authors as fault zones controlled by inversion (e.g., Nováková, 2014), strike-slip (Wojewoda and Kowalski, 2016) and even flexural (Valenta et al., 2008) tectonics. The total absence of inverse faults and pop-up structures in the study area especially in the vicinity of the LF and other recognized faults, significantly contradicts the opinion about strong subhorizontal compression (Prouza et al., 2015) produced by the "Alpine orogeny" (Tásler et al., 1979; Kozdrój and Cymerman, 2003) within investigated part of the IS. Described structures confirm the thesis about the permanent extensional development of the IS, proposed by other authors (Wojewoda, 2007; Wojewoda et al., 2016). It should be also emphasized that the Triassic and Cretaceous sediments do not show any evidence of continuous deformations. Changes in dip orientations of the sedimentary rocks are caused only by brittle faulting (Fig. 12) linked with the Cenozoic (Miocene?) stage of basin inversion. This stage of the IS development was termed earlier as the "Saxonian tectonogenesis" (Jerzykiewicz, 1971; Tásler et al., 1979; Stejskal et al., 2012). The terms brachyanticline or brachysyncline are usually applied to folds whose amplitude decreases to zero in both directions (Park, 2005). There is no evidence of the presence of brachyfolds or folds in the study area. Hence, the term "Łączna Elevation" is adequate and correct in the case of the study area and reflects its morphological and structural position.

Acknowledgements. I am grateful to J. Wojewoda for his strong support and inspiring suggestions. I would like to thank A. Żylińska for the linguistic improvement of the final version of this paper. Many thanks go to S. Madej for help with petrographic analyses. The three anonymous reviewers are acknowledged for their critical reading and valuable comments to the first version of the manuscript. Finally, I am grateful to T.M. Peryt, for his help during the review process. LiDAR data have been used for this study on the basis of the academic license No. DIO.DFT.DSI.7211.1619.2015 PL N issued for the University of Wrockaw by the Head Office of Geodesy and Cartography in Poland.

\section{REFERENCES}

Aleksandrowski, P., 1998. The Intra-Sudetic Fault Zone and the Variscan strike-slip tectonics in the West Sudetes. Geolines, 6 6-8.

Aleksandrowski, P., Śliwiński, W., Wojewoda, J., 1986. Frontally and surficially fluidized slump to debris flow sheets in an alluvial sequence, Lower Permian, Intrasudetic Basin. 7th IAS Regional Meeting: 9-29. Polish Academy of Sciences, Ossolineum, Kraków.

Anders, M.H., Schlische, R.W., 1994. Overlapping faults, intrabasin highs, and the growth of normal faults. The Journal of Geology, 102: 165-180.

Berg, G., Dathe, E., 1905/1906. Geologische Karte von Preußen und benachbarten Bundesstaaten (in German). Blatt Schömberg. Preußischen Geologischen Landesalstalt, Berlin.

Berg, G., 1909. Erläuterungen zur Geologischen Karte von Preußen und benachbarten Bundesstaaten. Lieferung 145. Schömberg (in German). Königlich Geologische Landesanstalt, Berlin.

Christie-Blick, N., Biddle, K.T., 1985. Deformation and basin formation along strike-slip faults. SEPM Special Publication, 37: 1-34.

Chrząstek, A., 2002. Stratigraphy and sedimentation conditions of Röt and Lower Muschelkalk of the North Sudetic Basin (in Polish with English summary). Acta Universitatis Wratislaviensis, 2383, Prace Geologiczno-Mineralogiczne, 73: 1-112.

Cymerman, Z., 1999. Alpine transpression in the Sudetes (SW Poland) (in Polish with English summary). Przegląd Geologiczny, 47: 942-945.

Cymerman, Z., 2004. Tectonic map of the Sudetes and the Fore-Sudetic Block. Polish Geological Institute, Warsaw.

Don, J., Jerzykiewicz, T., Teisseyre, A.K., Wojciechowska, I., 1979. Szczegółowa mapa geologiczna Sudetów 1:25 000, arkusz Lubawka (in Polish). Wyd. Geol., Warszawa.

Don, J., Jerzykiewicz, T., Teisseyre, A.K., Wojciechowska, I. 1981. Objaśnienia do Szczegółowej mapy geologicznej Sudetów, arkusz Lubawka 1:25 000 (in Polish). Wyd. Geol., Warszawa.
Dooley, T., Schreurs, G., 2012. Analogue modelling of intraplate strike-slip tectonics: a review and new experimental results. Tectonophysics, 574-575: 1-71.

Dooley, T., Monastero, F.C., Hall, B., McClay, K., Whitehouse, P., 2004. Scaled sandbox modeling of transtensional pull-apart basins - applications to the Coso Geothermal System. Geothermal Resources Council Transactions, 28: 637-642.

Dvořák, J., 1968. Stratigrafie, litologie a podloží svrchni kř́ídy ve vnitrosudetské pánvi (in Czech). Věstník Českého geologického ústavu, 43: 423-430.

Dziedzic, K., 1961. Lower Permian of the Intra Sudetic Basin (in Polish with English summary). Studia Geologica Polonica, 6: $1-121$

Engelder, T., 1989. Analysis of pinnate joints in the Mount Desert Island granite: implications for postintrusion kinematics in the coastal volcanic belt, Maine. Geology, 17: 564-567.

Flegel, K., 1904. Heuscheuer und Adersbach-Weckelsdorf. Eine Studie über die obere Kreide im böhmisch-schlesischen Gebirge. Jahres-Bericht Schlesischen der Gesellschaft für vaterländische Kultur, 82: 114-144.

Geinitz, H. B., 1848. Über obern Quader (in German). Neues Jahrbuch für Mineralogie, Geognosie, Geologie und Petrefaktenkunde: $778-780$.

Grocholski, A., 1971. Szczegółowa mapa geologiczna Sudetów 1:25 000, arkusz Mieroszów (in Polish). Wyd. Geol., Warszawa.

Grygar, R., Jelinek, J., 2003. Upper Morava and Nysa pull-apart grabens: implication for neotectonic dextral transtension on Sudetic faults system. Geolines, 16: 35-36.

Hancock, P.L., 1985. Brittle microtectonics: principles and practice. Journal of Structural Geology, 7: 437-457.

Herman, G.C., 2009. Steeply-dipping extension fractures in the Newark basin, New Jersey. Journal of Structural Geology, 31: 996-1011.

Holub, V., 1966. Geologické Poměry Východního Podkrkonoší (in Czech). Unpublished report. Geofond ČR, Prague.

Holub, V., 1972. Permian of the Bohemian Massif. In: Rotliegend Essays on European Lower Permian (ed. H. Falke): 137-188. Brill, Holland. 
Hölzel, M., Wagreich, M., Faber, R., Strauss, P., 2008. Regional subsidence analysis in the Vienna Basin (Austria). Austrian Journal of Earth Sciences, 101: 88-98.

Hus, R., Acocella, V., Funiciello, R., De Batist, M., 2005. Sandbox models of relay ramp structure and evolution. Journal of Structural Geology, 27: 459-473.

Jerzykiewicz, T., 1968. Remarks on the origin and orientation of joints in the Upper Cretaceous rocks of the Intrasudetic Basin (in Polish with English summary). Geologia Sudetica, 4: 465-478.

Jerzykiewicz, T., 1969. The brachysyncline of Krzeszów as a tectonic unit (Middle Sudetes). Bulletin de l'Académie Polonaise des Sciences, Serie des Sciences Geologiques et Geographiques, 17: 37-41.

Jerzykiewicz, T., 1971. Cretaceous in the vicinity of Krzeszów (in Polish with English summary). Geologia Sudetica, 5: 281-318.

Kondracki, J., 2002. Geografia Regionalna Polski, wyd. 3. PWN, Warszawa.

Kowalski, A., 2016. Granica trias-kreda na obszarze brachysynkliny Krzeszowa i elewacji Łącznej (synklinorium śródsudeckie) (in Polish). VI Polska Konferencja Sedymentologiczna POKOS 6 "Granice Sedymentologii", 28.06.2016-1.07.2016, Chęciny-Rzepka: 161-162. Instytut Geologii Podstawowej Wydziału Geologii Uniwersytetu Warszawskiego, Warszawa.

Kowalski, A., 2017. Impact of mass movements on geological interpretation - an example of the Drogosz hill landslide within the Zawory Range (Central Sudetes) (in Polish with English summary). Przegląd Geologiczny, 65: 96-104.

Kozdrój, W., Cymerman, Z., 2003. Alpine tectonic inversion - principal mechanism of the Variscan basement uplift and exhumation in the Sudety Mts. Geolines, 16: 59-60.

Marín-Lechado, C., Galindo-Zaldívar, J., Rodríguez-Fernández, L.R., González-Lodeiro, F., 2004. Faulted hybrid joints: an example from the Campo de Dalias (Betic Cordilleras, Spain) Journal of Structural Geology, 26: 2025-2037.

Mazur, S., Aleksandrowski, P., Kryza, R., Oberc-Dziedzic, T., 2006. The Variscan Orogen in Poland. Geological Quarterly, $\mathbf{5 0}$ (1): $89-118$

McClay, K., Bonora, M., 2001. Analog models of restraining stepovers in strike-slip fault systems. AAPG Bulletin, 85: 233-260.

Mierzejewski, M., 2015. Plumose and conchoidal structures on the joint surfaces of the Middle Turonian sandstone of the Stołowe Mts., Sudetes (SW Poland) (in Polish with English summary). Przegląd Geologiczny, 63: 426-428.

Mikuláš, R., Plička, M., Skalický, J., 1991. A find of mud scrolls in Lower Triassic sandstone at the locality Devět kř́žzu (NE Bohemia). Véstník Ústředního ústavu geologického, 66: 247-249.

Mroczkowski, J., 1977. Lower Triassic sandstones in the northern part of the Intra-Sudetic trough (in Polish with English summary). Annales Societatis Geologorum Poloniae, 47: 49-72.

Myers, R., Aydin, A., 2004. The evolution of faults formed by shearing across joint zones in sandstone. Journal of Structural Geology, 26: 947-966.

Nemec, W., Porębski, S.J., Teisseyre, A.K., 1982. Explanatory notes to the lithotectonic molasse profile of the Intra-Sudetic Basin, Polish part (Sudety Mts., Carboniferous-Permian). Veröffentlichung der Zentralinsitut für Physik der Erde, 66: 267-278.

Nováková, L., 2014. Evolution of paleostress fields and brittle deformation in Hronov-Poříčí Fault Zone, Bohemian Massif. Studia Geophysica et Geodaetica, 58: 269-288

Park, R.G., 2005. Foundations of Structural Geology (3rd edition) Aingdon, England.

Peacock, D.C.P., Sanderson, D.J., 1991. Displacements, segment linkage and relay ramps in normal fault zones. Journal of Structural Geology, 13: 721-733.

Peacock, D.C.P., Sanderson, D.J., 1995. Strike-slip relay ramps. Journal of Structural Geology, 17: 1351-1360.

Petit, J.P., 1987. Criteria for the sense of movement on fault surfaces in brittle rocks. Journal of Structural Geology, 9: 597-608.
Petrascheck, W., 1933. Der böhmische Anteil der Mittelsudeten und sein Vorland (in German). Mitteilungen der Geologischen Gesellschaft, 26: 1-136.

Pettijohn, F.J., 1975. Sedimentary Rocks (3rd edition). Harper and Row, New York.

Pluijm, van der, B., Marshak, S., 2004. Earth Structure. An Introduction to Structural Geology and Tectonics. WW Norton \& Company, New York.

Pollard, D.D., Aydin, A., 1988. Progress in understanding jointing over the past century. GSA Bulletin, 100: 1181-1204.

Porębski, S.J., 1980. Świebodzice succession, Upper Devonianlowermost Carboniferous, Western Sudetes: a prograding mass-flow dominated fan-delta complex (in Polish with English summary). Geologia Sudetica, 16: 101-192.

Prouza, V., Tásler, R., Valin, F., Holub, V., 1985. Gravelly to sandy braidplain deposition in the Buntsandstein-facies Bohdašín Formation in Northeastern Bohemia (Czechoslovakia). In: Aspects of Fluvial Sedimentation in the Lower Triassic Buntsandstein of Europe (ed. D. Mader): 397-410. Springer, Berlin.

Prouza, V., Coubal, M., Adamovič, J., 2015. Specific architecture of the Hronov-Poŕíći Fault (in Czech). Zprávy o geologických výzkumech v roce 2014. Geoscience Research Reports, 48 13-18.

Puc, B., Traczyk, A., 2006. Rzeźba strukturalna Zaworów w okolicach Chełmska Śląskiego (Sudety Środkowe) (in Polish). Przyroda Sudetów, 9: 169-178.

Radwański, S., 1966. Upper Cretaceous facies and faunas in the central part of the Sudety Mts. (in Polish with English summary) Annales Societatis Geologorum Poloniae , 36: 99-119.

Ramsay, J.G., 1980. The crack-seal mechanism of rock deformation. Nature, 284: 135-139.

Raumer, K., 1819. Das Gebirge Nieder-Schlesiens, der Grafschaft Glatz und eines Theils von Böhmen und der Ober-Lausitz geognostisch dergestelt (XVI) (in German). Berlin.

Sims, D., Ferrill, A., Stamatakos, J.A., 1999. Role of a ductile décollement in the development of pull-apart basins: experimental results and natural examples. Journal of Structural Geology, 21: 533-554.

Skoček, V., Valečka, J., 1983. Paleogeography of the Late Cretaceous Quadersandstein of Central Europe. Palaeogeography, Palaeoclimatology, Palaeoecology, 44: 71-92.

Stejskal, V., Valenta, J., Vilímek, V., 2012. Using geomorphological and geophysical survey to research relations between landforms and joint tectonics in the Broumovská vrchovina (Czech Republic). AUC Geographica, 47: 73-83.

Sugan, M., Wu, J.E., McClay, K., 2014. 3D analogue modelling of transtensional pull-apart basins: comparison with the Cinarcik basin, Sea of Marmara, Turkey. Bollettino di Geofisica Teorica ed Applicata, 55: 699-714

Sylvester, A.G., 1988. Strike-slip faults. GSA Bulletin, 100 1666-1703.

Śliwiński, W., 1981. Dolomites in the Chełmsko Śląskie Beds (Permian, Intra-Sudetic Basin), a reminiscence of the Permian volcanism (in Polish with English summary). In: Problems of Hercynian Volcanism in Central Sudetes (ed. K. Dziedzic), Abstracts: 106-110. Wydawnictwo Uniwersytetu Wrocławskiego.

Śliwiński, W., 1984. Proposed revision of the stratigraphic position of Chełmsko Ślaskie Beds (Permian, Intra-Sudetic Basin) (in Polish with English summary). Geologia Sudetica, 18: 167-174.

Tásler, R., 1964. Permokarbon vnitrosudetské pánve a podkrkonošské panve (in Czech). In: Regionální geologie ČSSR. Díl I, Český masív, sv. 2. Algonkium až kvartér: 204-232. Ústřední ústav geologický, Praha.

Tásler, R., Čadková, Z., Dvořák, J., Fediuk, F., Chaloupský, J. Jetel, J., Kaiserová-Kalibová, M., Prouza, V., SchovánkováHrdličková, D., Středa, J., Stríída, M., Šetlík, J., 1979. Geology of the Bohemian part of the Intra-Sudetic Basin (in Czech with English summary). Oblastní regionální geologie CSR. Ústřední ústav geologický, Praha.

Tułaczyk, S., 1992. Cuesta landscape in the middle part of the Sudetes Mts. Geographia Polonica, 60: 137-150. 
Turnau, E., Żelaźniewicz, A., Franke, W., 2002. Middle to early late Viséan onset of late orogenic sedimentation in the Intra-Sudetic Basin, West Sudetes: miospore evidence and tectonic implication. Geologia Sudetica, 34: 9-16.

Uličný, D., 1999. Interplay of strike-slip tectonics and eustasy in coarse-grained delta systems, Bohemian Cretaceous Basin. Geolines, 8: 72 .

Uličný, D., 2001. Depositional systems and sequence stratigraphy of coarse-grained deltas in a shallow-marine, strike-slip setting: the Bohemian Cretaceous Basin, Czech Republic. Sedimentology, 48: 599-628.

Uličný, D., 2004. A drying-upward aeolian system of the Bohdašín Formation (Early Triassic), Sudetes of NE Czech Republic: record of seasonality and long-term palaeoclimate change. Sedimentary Geology, 167: 17-39.

Valenta, J., Stejskal, V., Štěpančíková, P., 2008. Tectonic pattern of the Hronov-Pořiči Trough as seen from pole-dipole geoelectrical measurements. Acta Geodynamica et Geomaterialia, 5: 185-195.

Wilkins, S.J., Gross, M.R., Wacker, M., Eyal, J., Engelder, T., 2001. Faulted joints: kinematics, displacement-length scaling relations and criteria for their identification. Journal of Structural Geology, 23: 315-327.

Wojewoda, J., 1997. Upper Cretaceous littoral-to-shelf succession in the Intrasudetic Basin and Nysa Trough, Sudety Mts. Obszary źródłowe: Zapis w Osadach, 1: 81-96.

Wojewoda, J., 2004. Tensyjny rozwój strefy Jawor-Złotoryja w neogenie (in Polish). In: Sudety Zachodnie: od wendu do czwartorzędu (ed. A. Żelaźniewicz): 127-135. WIND, Wrocław.

Wojewoda, J., 2007. Neotectonic aspect of the Intrasudetic Shear Zone. Acta Geodynamica et Geomaterialia, 4 (148): 31-41.

Wojewoda, J., 2008. Diffusional cells - an example of differentiated rheological reaction of granular sediment to seismic shock (in Polish with English summary). Przegląd Geologiczny, 56: 842-847.

Wojewoda, J., 2009. Žd’arky-Pstrążna Dome: a strike-slip fault-related structure at the eastern termination of the Porríčí-Hronov Fault Zone (Sudetes). Acta Geodynamica et Geomaterialia, 6: 273-290.
Wojewoda, J., 2012. Joints in Cretaceous sandstones of the Góry Stołowe mountains: tectonic and non-tectonic. 13th Czech-Polish Workshop On Recent Geodynamics of the Sudeten and Adjacent Areas. Wrocław-Pawłowice, Poland, November 22-24, 2012: 61. Institute of Geodesy, Brno University of Technology, Brno.

Wojewoda, J., Kowalski, A., 2016. Rola południowo-sudeckiej strefy ścinania w ewolucji Sudetów (in Polish). In: Wyzwania polskiej geologii, 3, Polski Kongres Geologiczny (eds. J. Wojewoda and A. Kowalski), Przewodnik do Wycieczek Kongresowych, wycieczka 2.3: 21-43. Polskie Towarzystwo Geologiczne.

Wojewoda, J., Mastalerz, K., 1989. Climate evolution, allo- and autocyclicity of sedimentation: an example from the Permo-Carboniferous continental deposits of the Sudetes, SW Poland (in Polish with English summary). Przegląd Geologiczny, 37: 173-180.

Wojewoda, J., Rauch, M., Kowalski, A., 2016. Synsedimentary seismotectonic features in Triassic and Cretaceous sediments of the Intrasudetic Basin (U Devíti křižů locality) - regional implications. Geological Quarterly, 60 (2): 355-364.

Wojtkowiak, A., Zawistowski, K., Ihnatowicz, A., Biel, A., 2011. Dokumentacja geologiczna z wykonania hydrogeologicznych otworów badawczych dla projektowanej Stacji Hydrogeologicznej I Rzędu w Dobromyślu (in Polish). Polish Geological Institute - Polish Research Institute.

Wu, J.E., McClay, K., Whitehouse, P., Dooley, T., 2009. 4D analogue modelling of transtensional pull-apart basins. Marine and Petroleum Geology, 26: 1608-1623.

Ziegler, P.A., 1987. Late Cretaceous and Cenozoic intra-plate compressional deformations in the Alpine foreland a geodynamic model. Tectonophysics, 137: 389-420.

Ziółkowska, M., 1990. Glauconite from the Upper Cretaceous deposits of the Inner Sudetic Depression (in Polish with English summary). Przegląd Geologiczny, 38: 433-437.

Żelaźniewicz, A., Aleksandrowski, P., Buła, Z., Karnkowski, P. H., Konon, A., Oszczypko, N., Ślączka, A., Żaba, J., Żytko, K., 2011. Regionalizacja Tektoniczna Polski (in Polish). KNG PAN, Wrocław. 